\title{
SYNTHESIS OF THE SOUTHEAST ATMOSPHERE STUDIES Investigating Fundamental Atmospheric Chemistry Questions
}

\author{
Annmarie G. Carlton, Joost de Gouw, Jose L. Jimenez, Jesse L. Ambrose, \\ Alexis R. Attwood, Steven Brown, Kirk R. Baker, Charles Brock, Ronald C. Cohen, \\ Sylvia Edgerton, Caroline M. Farkas, Delphine Farmer, Allen H. Goldstein, lynne Gratz, \\ Alex Guenther, Sherri Hunt, Lyatt Jaeglé, Daniel A. Jaffe, John Mak, Crystal McClure, \\ Athanasios Nenes, Thien Khoi Nguyen, Jeffrey R. Pierce, Suzane de Sa, Noelle E. Selin, Viral Shah, \\ Stephanie Shaw, Paul B. Shepson, Shaojie Song, Jochen Stutz, Jason D. Surratt, Barbara J. Turpin, \\ Carsten Warneke, Rebecca A. Washenfelder, Paul O. Wennberg, and Xianling Zhou
}

\begin{abstract}
Scientific research findings that span large concurrent field campaigns during the summer of 2013 in the southeast United States are synthesized and discussed.
\end{abstract}

$\mathrm{T}$ he World Health Organization (WHO; WHO 2014), United Nations (UN; IRAC 2013), and Intergovernmental Panel on Climate Change (IPCC; IPCC 2014) state that the global population is negatively impacted by climate change and degraded air quality. Development of successful strategies to alleviate the most severe environmental outcomes is mired with uncertainty, in part due to an inability to accurately predict the complex atmospheric processes that are responsible for and respond to pollution. The Southeast Atmosphere Studies (SAS) science topics were chosen to contribute to elucidation of these processes and feedbacks: 1) atmosphere-biosphere interactions, 2) nitrogen chemistry during the day and night, 3) anthropogenic emissions and the related trends in ambient concentrations, 4) atmospheric mercury, 5) gas-phase and multiphase chemical mechanisms, 6) the organic aerosol budget, and 7) climate-relevant properties of aerosol. Resolving key scientific questions in these topic areas on a time scale relevant to addressing environmental and human-health impacts requires coordination among diverse researchers at different institutions working toward common goals and freely sharing information. Understanding, and recreating in models, the response in ambient concentrations from changes in emissions, chemistry, and meteorology is essential to provide guidance to policy makers who can then develop effective strategies to manage air resources, especially in a changing global climate (Gilliland et al. 2008; Jacob and Winner 2009). Accurate and reliable projections for the future atmosphere require that models not only accurately describe current atmospheric concentrations, but do so for the right reasons. Only through incorporation of the correct mechanisms evaluated against observations can future projections of the impacts from policy, energy, and climate scenarios be considered robust. This overview focuses on the scientific rationale behind the SAS studies and provides a broad description of experimental platforms (Fig. 1 and table 1) with an emphasis on deployment strategy, key findings 
to date, and strategic goals for coordinated future directions, including modeling studies from local to global scales and data mining of the thousands of measurements.

The southeast United States (SEUS) is an ideal location to investigate the fundamental atmospheric processes that determine climate and air quality. The SEUS has not warmed over the past 100 years, contrary to the trend observed in most locations globally (IPCC 2013). The regional anomaly is referred to as the "warming hole" (Meehl et al. 2012; Portmann et al. 2009), though in the past decade the region has warmed (Yu et al. 2014). Atmospheric scientists have discussed a variety of local- and large-scale explanations to explain the regional phenomenon, but consensus remains elusive. Changes in soil moisture feedbacks (Pan et al. 2004), circulation modes (e.g., Southern Oscillation; Portmann et al. 2009), cumulus clouds (Liang et al. 2006), sea surface temperature (Robinson et al. 2002), internal dynamic variability (Kunkel et al. 2006), moisture convergence patterns (Meehl et al. 2012), and land surface processes (Pan et al. 2013) have been proposed to contribute to the SEUS anomaly. Another hypothesis is that short-lived climate forcers, in particular secondary aerosols (particles that form in situ and not directly emitted), impact regional climate of the humid and photochemically active SEUS (Goldstein et al. 2009; Leibensperger et al. 2012), and this is debated (Banerjee et al. 2017). Temporal trends of anthropogenic sulfur dioxide emissions and the resulting ambient formation of sulfate aerosol are consistent
AFFILIATIONS: CARLton,* FARKAS, and NGUYEN-Department of Environmental Science, Rutgers, The State University of New Jersey, New Brunswick, New Jersey; DE Gouw, AtTwood,* AND Brown-Chemical Sciences Division, NOAA/Earth System Research Laboratory, Boulder, Colorado; JIMENEZ-Department of Chemistry, and CIRES, University of Colorado Boulder, Boulder, Colorado; Ambrose,* Gratz,* AND JAEGLÉ-School of Science, Technology, Engineering and Mathematics, University of Washington Bothell, Bothell, Washington; BAKER-Office of Air Quality Planning and Standards, U.S. Environmental Protection Agency, Research Triangle Park, North Carolina; BrockDepartment of Chemistry, University of California, Irvine, Irvine, California; COHEN-Department of Chemistry, and Department of Earth and Planetary Science, University of California, Berkeley, Berkeley, California; EDGERTON-National Science Foundation, Arlington, Virginia; FARMER-Department of Chemistry, Colorado State University, Fort Collins, Colorado; GoLDSTEIN-Department of Environmental Science, Policy and Management, University of California, Berkeley, Berkeley, California; GUENTHER_Department of Earth System Science, University of California, Irvine, Irvine, California; HUNT—Office of Research and Development, U.S. Environmental Protection Agency, Washington, D.C.; JAFFE AND MCCluRE-School of Science, Technology, Engineering and Mathematics, University of Washington Bothell, Bothell, and Department of Atmospheric Sciences, University of Washington, Seattle, Washington; MAK-School of Marine and Atmospheric Sciences, Stony Brook University, State University of New York, Stony Brook, New York; Nenes*-Earth and Atmospheric Sciences, Georgia Institute of Technology, Atlanta, Georgia; PIERCEDepartment of Atmospheric Science, Colorado State University, Fort Collins, Colorado; DE SA-School of Engineering and Applied Science, Harvard University, Cambridge, Massachusetts; SeLINInstitute for Data, Systems, and Society, and Department of Earth, Atmospheric, and Planetary Sciences, Massachusetts Institute of Technology, Cambridge, Massachusetts; SHAH-Department of Atmospheric Sciences, University of Washington, Seattle, Washington; SHAW-Electric Power Research Institute, Palo Alto, California; ShePson-Department of Chemistry, Purdue
University, West Lafayette, Indiana; SoNG—Department of Earth, Atmospheric, and Planetary Sciences, Massachusetts Institute of Technology, Cambridge, Massachusetts; StuTz-Department of Atmospheric and Oceanic Sciences, University of California, Los Angeles, Los Angeles, California; SURRATT AND TURPIN-Department of Environmental Science and Engineering, Gillings School of Global Public Health, University of North Carolina at Chapel Hill, Chapel, Hill, North Carolina; WARNeKe AND WASHenfelder-Chemical Sciences Division, NOAA/Earth System Research Laboratory, and CIRES, University of Colorado Boulder, Boulder, Colorado; WeNNBERG-Division of Engineering and Applied Science, and Division of Geological and Planetary Sciences, California Institute of Technology, Pasadena, California; ZHOU-Wadsworth Center, New York State Department of Health, and Department of Environmental Health Sciences, University at Albany, State University of New York, Albany, New York

*ADDITIONAL AFFILIATIONS: CARLTON-Department of Chemistry, University of California, Irvine, Irvine, California; AMBROSE-College of Engineering and Physical Sciences, University of New Hampshire, Durham, New Hampshire; ATTwOOD—Droplet Measurement Technologies, Longmont, Colorado; GratzEnvironmental Program, Colorado College, Colorado Springs, Colorado; NeNEs*-Institute of Chemical Engineering Sciences, Foundation for Research and Technology Hellas, Patras, Greece, and Institute for Environmental Research and Sustainable Development, National Observatory of Athens, Palea Peteli, Greece

CORRESPONDING AUTHOR: Annmarie G. Carlton, agcarlto@uci.edu

The abstract for this article can be found in this issue, following the table of contents.

DOI:10.1175/BAMS-D-16-0048.I

A supplement to this article is available online (I0.II75/BAMS-D-16-0048.2)

In final form 17 August 2017

(C)2018 American Meteorological Society

For information regarding reuse of this content and general copyright information, consult the AMS Copyright Policy. 
with regional temperature trends (Leibensperger et al. 2012). Secondary organic aerosol (SOA) formed aloft from a combination of anthropogenic and biogenic emissions in the SEUS has also been hypothesized to contribute to summertime aerosol optical thickness in the region (Goldstein et al. 2009; Ford and Heald 2013), potentially influencing temperature (Goldstein et al. 2009; Portmann et al. 2009). The high rates of anthropogenic and biogenic emissions in the SEUS, where conditions favor rapid gas- and multiphase
WP-3D Flights (SENEX)

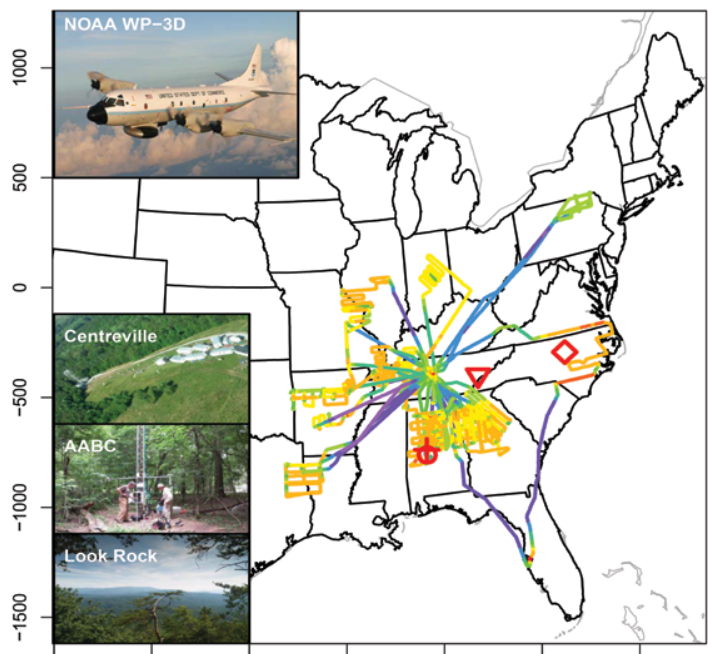

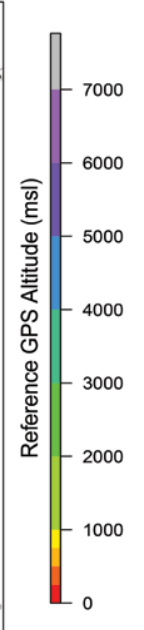

FIG. I. SAS platforms and locations. Flight tracks are shown for (left) NOAA WP-3D aircraft during SENEX and (right) NSF/NCAR C-I30 during NOMADSS.

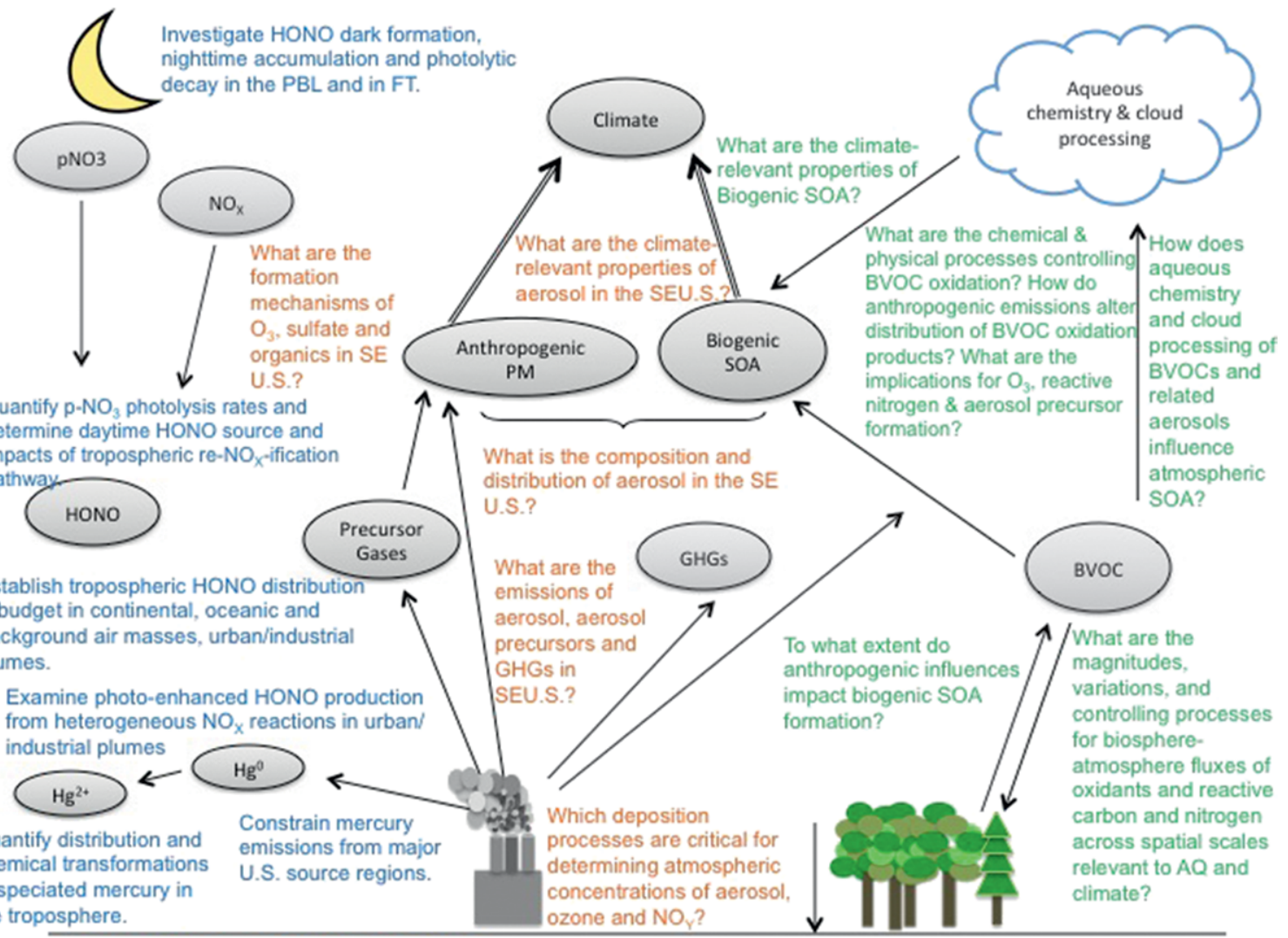

NOMADSS SENEX SOAS




photochemistry, facilitate formation of ozone (Chameides et al. 1988) and SOA (Weber et al. 2007).

The Southern Oxidant Study (SOS), the largest previous SEUS intensive, spanned nearly a decade (1990s) involving several sites around Nashville, Tennessee; Atlanta, Georgia; and other locations, as well as the operation of several research aircraft (NCSU 2016). Analyses of SOS observations led to fundamental discoveries about mechanisms affecting atmospheric composition, particularly the importance of biogenic isoprene in regional ozone formation (Chamiedes et al. 1988). Application of these discoveries redefined air quality management for ozone in the eastern United States. The Southeastern Aerosol and Visibility Study (SEAVS) in 1995 in the Great Smoky Mountains National Park (Andrews et al. 2000) contributed to our understanding of regional haze. Subsequent observations of long-term trends, in particular from multiyear monitoring stations [e.g., Interagency Monitoring of Protected Visual Environments (IMPROVE; IMPROVE 2016), Chemical Speciation Network (CSN; U.S. EPA 2016), and Southeastern Aerosol Research and Characterization (SEARCH; ARA 2016)], have provided constraints on our understanding of atmospheric processes and the models used to describe them and link sampling intensives to a broader context.

During the $20+$ years since SOS, analytical instrumentation for laboratory and in situ measurements has vastly improved in temporal resolution, sensitivity, and spectrum of measurable compounds. It is now possible to explicitly quantify a variety of gas- and particle-phase species in near-real time, including "sticky" compounds (e.g., glyoxal and some multifunctional compounds), very short-lived species (e.g., radicals), and gas- and particle-phase oxidation products traceable to specific organic precursors. Surface- and space-based measurements of aerosol optical depth are now routine and publically available (Holben et al. 1998; Martin 2008). These platforms have recorded changes in columnar loadings of trace species with geographic coverage not possible from other platforms. During previous SEUS intensive observation periods, the large confluence of such measurement techniques was not available, thus limiting potential discovery.

Thousands of physically and chemically diverse measurements from different surface sites and research aircraft (Table 1) collected during SAS are now available for use by anyone. Chemical insights developed from SAS data improve representation of chemical processes in atmospheric models of different temporal and spatial scales. Detailed analysis of climate-relevant aerosol properties observed during SAS similarly provides a valuable opportunity to evaluate, diagnose, and improve climate models. Coordinated investigation from chemical and physical perspectives within the atmospheric sciences community may improve predictive capability for air quality and climate, in particular for describing the consequences of future policy decisions and energy choices.

\section{SAS PLATFORM DESIGN AND SCIENCE STRATEGY. SAS measurement platforms were} optimized for coordinated investigation of open science questions spanning three component projects: the Southern Oxidant and Aerosol Study (SOAS); the Southeast Nexus (SENEX) campaign; and the Nitrogen, Oxidants, Mercury and Aerosols: Distributions, Sources and Sinks (NOMADSS) experiment (Fig. 2). Air quality modeling was employed to inform the individual ground-site locations based on the likelihood to experience a range of chemical conditions (Carlton et al. 2011), and chemical forecasting was used to plan aircraft flight patterns. The SAS platforms included heavily instrumented ground sites in Centreville (CTR) and Birmingham, Alabama; Look Rock (LRK), Tennessee; the Appalachian Atmospheric Interdisciplinary Research (AppalAIR) site near Boone, North Carolina; and Research Triangle Park, North Carolina, in addition to a flux tower in Alabama (Table 1). Four samplingintensive periods, in which particle samples were collected with higher time resolution, were coordinated among the Centreville (CTR), Birmingham, and Look Rock (LRK) sites. The CTR supersite in Brent, Alabama, is the location of a routine monitoring network site, part of the SEARCH network. The site provides context to the SAS campaign with over a decade of meteorology, trace-gas, and particle-species concentrations (Hidy et al. 2014). Additionally, four aircraft, the National Science Foundation (NSF)/National Center for Atmospheric Research (NCAR) C-130, the National Center for Ocean and Atmospheric Administration (NOAA) WP-3D (both operated out of Smyrna, Tennessee), Purdue University's Duchess, and the Stony Brook University Long-EZ, measured trace species aloft and helped characterize biogenic emissions, point-source emissions, and evolution of chemical species from plumes to regional scales (Fig. 2). A critical component of the SAS campaign included long (up to 6 weeks) measurement intercomparisons and coordinated calibrations at the main SAS ground site, CTR. Joint measurements across research groups under field conditions added to the overall quality assurance and quality control of SAS. 
TABLE I. SAS platform locations and descriptions.

SURFACE PLATFORMS

\begin{tabular}{|c|c|c|c|}
\hline Latitude $\left({ }^{\circ}\right)$ & Longitude $\left({ }^{\circ}\right)$ & Elevation (m) & Description \\
\hline \multirow{3}{*}{32.90289} & \multirow{3}{*}{-87.24968} & \multirow{3}{*}{126} & Centerville (CTR) site \\
\hline & & & $\begin{array}{l}\text { Chemical speciation, chemically characterized gas and aerosol } \\
\text { measurements, detailed meteorology }\end{array}$ \\
\hline & & & $\begin{array}{l}\text { Data available at } \\
\text { www.esrl.noaa.gov/csd/groups/csd7/measurements/20 I 3senex/ }\end{array}$ \\
\hline \multirow{4}{*}{32.69456} & \multirow{4}{*}{-87.2488} & \multirow{4}{*}{ Multiple heights } & $\begin{array}{l}\text { Flux tower at Alabama Aquatic Biological Diversity Center } \\
(\mathrm{AABC})\end{array}$ \\
\hline & & & Fluxes, soil temperature, radiation \\
\hline & & & $\begin{array}{l}\text { Integrated Surface Flux Facility } \\
\text { (www.eol.ucar.edu/observing_facilities/isfs) }\end{array}$ \\
\hline & & & Data available at www.eol.ucar.edu/node/654 \\
\hline \multirow{3}{*}{32.892747} & \multirow{3}{*}{-87.248515} & \multirow{3}{*}{ Multiple heights } & CTR Meteorology at surface, soundings, lidar \\
\hline & & & $\begin{array}{l}\text { Integrated Sounding System } \\
\text { (www.eol.ucar.edu/instrumentation/sounding/iss) }\end{array}$ \\
\hline & & & Data available at www.eol.ucar.edu/node/654 \\
\hline \multirow{3}{*}{35.63314} & \multirow{3}{*}{$-83.94 \mid 85$} & \multirow{3}{*}{802} & Look Rock (LRK) site \\
\hline & & & Surface chemical speciation \\
\hline & & & $\begin{array}{l}\text { Data available at } \\
\text { www.esrl.noaa.gov/csd/groups/csd7/measurements/20 I 3senex/ }\end{array}$ \\
\hline \multirow{3}{*}{35.889455} & \multirow{3}{*}{-78.874694} & \multirow{3}{*}{325} & Research Triangle Park \\
\hline & & & Surface chemical speciation \\
\hline & & & $\begin{array}{l}\text { Data available at } \\
\text { www.esrl.noaa.gov/csd/groups/csd7/measurements/20I3senex/ }\end{array}$ \\
\hline \multirow{2}{*}{36.21} & \multirow{2}{*}{-81.69} & \multirow{2}{*}{1000} & AppalAIR \\
\hline & & & Surface chemical speciation \\
\hline
\end{tabular}

AIRCRAFT PLATFORMS

\begin{tabular}{|c|c|}
\hline \multirow[b]{2}{*}{ NOAA WP-3D } & Flight tracks in Fig. I (left) \\
\hline & $\begin{array}{l}\text { Data available at } \\
\text { www.esrl.noaa.gov/csd/groups/csd7/measurements/20I3senex/ }\end{array}$ \\
\hline \multirow[b]{2}{*}{ NSF/NCAR C-I 30} & Flight tracks in Fig. I (right) \\
\hline & $\begin{array}{l}\text { Data available at } \\
\text { www.esrl.noaa.gov/csd/groups/csd7/measurements/20 I 3senex/ }\end{array}$ \\
\hline Purdue Duchess & $\begin{array}{l}\text { Data available at } \\
\text { www.esrl.noaa.gov/csd/groups/csd7/measurements/20 I 3senex/ }\end{array}$ \\
\hline Stony Brook Long-EZ & $\begin{array}{l}\text { Data available at } \\
\text { www.esrl.noaa.gov/csd/groups/csd7/measurements/20I3senex/ }\end{array}$ \\
\hline
\end{tabular}

For example, instruments measuring the same trace species were brought together in close proximity in the field and/or sampled from the same inlet manifold for measurement intercomparison. Two 1-day case studies for particle volume and number concentration are shown in the online supplement (https://doi .org//0.II75/BAMS-D-16-0048.2). Another critical component of SAS was a coordinated postcampaign laboratory experiment [Focused Isoprene Experiment at the California Institute of Technology (FIXCIT)] in a controlled environmental chamber operated at conditions sampled during SAS to test field hypotheses and investigate measurement discrepancies relevant to atmospheric isoprene oxidation (T. B. Nguyen et al. 2014a). Such approaches help to connect findings among field campaigns and enhance potential synergies among research groups.

FIXCIT directly reconciled measurement interferences that confound field interpretation of first-generation hydroperoxides ("low" NO product) 
and the "high" NO products, methyl vinyl ketone and metachrolein (MACR; Rivera-Rios et al. 2014). In this context, high-NO conditions indicate $\mathrm{RO}_{2}$ radical reaction with $\mathrm{NO}$ is favored over reaction with the hydroperoxyde radical $\left(\mathrm{HO}_{2}\right)$. Through explicit simultaneous chemical characterization of gas- and particle-phase products, FIXCIT identified a previously uncharacterized low-NO aerosol formation pathway (Krechmer et al. 2015), provided first experimental evidence for theory-predicted lactone production, and demonstrated sensitivity of SOA production to aerosol liquid water (T. K. V. Nguyen et al. 2015). FIXCIT characterized isoprene $\mathrm{NO}_{3}$-initiated oxidation products for the first time and provided the most comprehensive isoprene-ozone reaction mechanism, specifically outlining the fate of radical Criegee intermediates (T. B. Nguyen et al.2016).

NASA's Studies of Emissions and Atmospheric Composition, Clouds, and Climate Coupling Regional Surveys (SEAC ${ }^{4} \mathrm{RS}$ ) campaign complemented SAS efforts. Among other science objectives, $\mathrm{SEAC}^{4} \mathrm{RS}$ also investigated chemical transformation in the troposphere of the SEUS in the context of changing anthropogenic emissions with key questions related to oil, gas, and fracking emissions; wildfires; and the ability to use satellites to understand tropospheric chemistry. SEAC ${ }^{4}$ RS's motivation and findings are discussed in detail by Toon et al. (2016). SEAC ${ }^{4} R S$ and SAS both found a changed chemical regime in the SEUS impacting ozone and particle formation from reduced emissions of sulfur dioxide $\left(\mathrm{SO}_{2}\right)$ and nitrogen oxides $\left(\mathrm{NO}_{x}\right)$ and large impact of wildfires on particle optical properties.

\section{METEOROLOGICAL AND CHEMICAL CLIMATOLOGY AT THE CENTREVILLE SUPERSITE DURING SAS. We describe condi-} tions in detail at the main ground site in Alabama, where the largest number of measurements were taken. SAS campaign meteorology (Fig. 3) was characterized by cooler-than-average air temperature and higher-than-average total rainfall when compared to nearly 120 years of meteorological data for the same time of year. The anomaly for maximum daily temperature in the area was $-1.7^{\circ} \mathrm{C}$. It was the eleventhwettest July since 1895 , with a precipitation anomaly of $+8.5 \mathrm{~cm}$. At CTR specifically, daytime temperatures (0600-1600 local time) were uncharacteristically low, outside the 25th-percentile median for the last decade (Fig. 4a). The CTR site experienced many afternoon convective thunderstorms and showers that at times were severe.

We describe synoptic meteorological conditions that impacted CTR during SAS. Convective thunderstorms were observed on the first day of SAS (1 June 2013) with nearly $2 \mathrm{~cm}$ of rain. Frontal passages and Tropical Storm Andrea to the east brought severe storms and approximately $7.8 \mathrm{~cm}$ of rain over a 3-day period (5-7 June). A synoptic quiet period followed, bringing high temperatures and little precipitation. The date of 13 June was marked by a cold-frontal passage with moderate rain. Another cold-frontal passage began 
on 18 June and moved through the area, becoming occluded before moving out of Alabama on 20 June. A final occluded front moved in on 29 June and affected CTR into early July. A synoptic cold front occurred on 12 July. The time period between fronts was marked by convective storms and rain. Rain during this period was due to moisture from the Gulf of Mexico mixed with convective thunderstorms. July 2013 experienced the second-coolest maximum temperatures in the upper plains region of Alabama since 1895.

Four intensive sampling periods were optimized with chemical forecasting; during each, filter-based particle measurements were conducted at a higher frequency (every $\sim 3 \mathrm{~h}$ during the day rather than typical 23-h daily average sampling) in a coordinated fashion across all SAS ground sites. Wind-direction frequencies of each of the four SAS intensive sampling periods (Fig. 3) at CTR are unique. West-southwest and south-southwest winds dominated the first intensive sampling period (10-12 June 2013). The second intensive period (14-16 June 2013) experienced variable winds from the north, north-northwest, and east-southeast, sharing near-equal frequency. The third intensive period (29 June-1 July 2013) experienced frequent 4-6 m $\mathrm{s}^{-1}$ winds, mainly from the west and west-northwest. The final and longest intensive period (9-14 July 2013) had variable winds, with south and north-northwest directions exhibiting the highest frequency.

The atmosphere at CTR experienced a range of chemical conditions from clean "background" conditions to episodic spikes in pollutant concentrations from anthropogenic sources. In general, when averaged over the campaign time period, ambient mixing ratios of $\mathrm{SO}_{2}, \mathrm{NO}_{x}$, and ozone $\left(\mathrm{O}_{3}\right)$ at CTR were lower than the 25th percentiles for the last decade (Figs. $4 \mathrm{~b}-\mathrm{d}$ ). These lower mixing ratios can be attributed to a general decreasing trend of $\mathrm{SO}_{2}$ and $\mathrm{NO}_{x}$ emissions traceable to U.S. environmental regulations (e.g., Blanchard et al. 2013a), such as Title IV of the 1990 Clean Air Act Amendments (Hand et al. 2012), fewer emissions due to a cooler summer with less electricity demand (Farkas et al. 2015), and increasing energy efficiency and economic recession (U.S. EIA 2016). During SAS, total daytime fine particulate matter $\left(\mathrm{PM}_{2.5}\right)$ mass was relatively constant (Fig. 4f). Particle organic carbon (OC) concentrations were similar to median concentrations over the previous decade, which have been measured every 3 days at CTR. Trends in particle mass and OC at CTR are in sharp contrast to substantial decreases of $\mathrm{SO}_{2}, \mathrm{NO}_{x}$, and $\mathrm{O}_{3}$ during the previous decade. Documented decreases in OC mass concentrations at SEARCH sites have been reported (Blanchard et al. 2016) and are more pronounced at urban locations than for rural sites (T. K. V. Nguyen et al. 2015; Blanchard et al. 2016). Overall, OC trends at CTR decrease modestly $(<8 \%)$ over the past decade. For individual months, the largest decadal decreases at CTR have predominantly occurred during winter months, outside the SAS time frame (Fig. ES3 in the online supplement). OC mass concentrations at CTR during June have increased relative to a minimum in 2002 (Fig. ES3). 
FINDINGS IN SAS SCIENCE TOPICS. The scientific findings from SAS are described in seven different categories that summarize the underlying science questions and motivating factors of the original campaigns. The topic areas are framed around answerable, open questions, to which substantial leaps in understanding are being made.

Atmosphere-biosphere interactions. SAS coordinated a comprehensive suite of ecosystem-atmosphere flux measurements on leaf, canopy, landscape, and regional scales. Instruments based on a mobile lift, above-canopy towers, and light aircraft platforms directly measured fluxes across leaf, canopy, and landscape scales at two representative forests (lowland and upland) near CTR. The processes investigated by these local-scale measurements were complemented by flux measurement systems on the NSF/NCAR C-130 and NOAA WP-3D aircraft that, along with satellite observations, extend the SAS land-atmosphere exchange measurements to most of the major ecosystems across the SEUS.

The overall atmosphere-biosphere interaction research question addressed by SAS is "what are the magnitudes, variations, and controlling processes for biosphere-atmosphere fluxes of oxidants and reactive carbon and nitrogen across spatial scales relevant for regional models?" Specific SAS scientific questions targeted oxidized volatile organic compound (VOC) deposition, "unknown" biogenic volatile organic carbon (BVOC) emission, BVOC emission response to land-cover change, and differences among BVOC emission estimation approaches.

Dry deposition is an important, but poorly quantified, sink for oxygenated VOCs and indirectly for SOA (e.g., Knote et al. 2015). Deposition of oxygenated and water-soluble VOCs, especially isoprene oxidation products, was measured by eddy covariance at both SAS flux tower sites using multiple types of chemical ionization mass spectrometry (CIMS) instruments. The measured deposition rates include compounds whose deposition had not previously been quantified (e.g., hydroxymethyl hydroperoxide, peroxyacetic acid, monoterpene nitrooxy hydroperoxide, and hydrogen cyanide). The measurements indicate that, for turbulent conditions, water solubility and molecular diffusivity drive the deposition velocities of atmospheric trace gases during SAS. Polar, water-soluble compounds that have negligible surface uptake resistance were observed to deposit at the diffusion limits dictated by their molecular size (T. B. Nguyen et al. 2015a). The resistance-in-series scheme used in many models was extended for larger oxygenated VOCs with a revised surface resistance parameterization, which primarily increased the sensitivity of the model to the water solubility of the depositing molecule. Implementing these changes into a global model increased the mean daytime deposition velocities for some compounds up to a factor of 2 and achieved better measurement-model agreement of trace-gas lifetimes and surface concentrations (T. B. Nguyen et al. 2015a).

Comprehensive measurements of leaf-, canopy-, and landscape-level isoprene and monoterpene concentrations and emissions at the two SAS tower sites presented a unique opportunity to constrain the processes controlling BVOC emissions in this region. The earlier SOS studies included only leaf-level emission measurements that represented just a small fraction of the ecosystem and were extrapolated to the canopy scale to predict fluxes into the above-canopy atmosphere (Guenther et al. 1996). The magnitude and diurnal variations of whole-canopy isoprene and monoterpene emissions measured during SAS compared well with both the extrapolation of leaf-level results and with vertical concentration profiles measured from the canopy to the top of the boundary layer (Su et al. 2016). The extensive eddy covariance isoprene and monoterpene flux measurements conducted during the NSF/NCAR C-130 flights, and the complementary measurements from the NOAA WP-3D flights, extend these constraints to other SEUS ecosystems (e.g., Kaser et al. 2015).

In addition to reducing the uncertainties associated with deposition and emission rates, accurate VOC flux measurements at multiple heights in the daytime boundary layer were used to constrain oxidation rates through hydroxyl radical $(\mathrm{OH})$ concentration estimates. Airborne isoprene flux measurements during SAS were used to estimate boundary layer $\mathrm{OH}$ concentrations of 2.8-6.6 $\times 10^{6}$ molecules per cubic centimeter that were within $16 \%$ of in situ aircraft CIMS measurements (Kaser et al. 2015). The reverse approach was used during the 1990s SOS campaigns to estimate isoprene and monoterpene emissions using measured isoprene and monoterpene concentrations combined with highly uncertain $\mathrm{OH}$ concentration estimates (Guenther et al. 1996). The comprehensive SAS emissions, chemistry, and dynamics observations also directly showed, for the first time, that the surface heterogeneity of isoprene emissions leads to a physical separation of isoprene and $\mathrm{OH}$, resulting in an effective slowdown of isoprene loss rates by up to $30 \%$ (Kaser et al. 2015). 
Nitrogen chemistry during day and night. $\mathrm{NO}_{x}$ regulates the rates and pathways of atmospheric oxidation, impacting ozone, aerosols, and climate. The SAS campaign brought a wide range of established and new technologies to study $\mathrm{NO}_{x}$ chemistry in the presence of high BVOC concentrations and provided an opportunity to explore changing $\mathrm{NO}_{x}$ chemistry as a result of dramatic decreases of anthropogenic emissions in the SEUS during the past two decades. Most of the region, in particular rural areas, was often in a chemical regime where small variations in $\mathrm{NO}_{x}$ affected the fate of peroxy radicals (Travis et al. 2016), and thus ozone and aerosol production efficiency, providing an opportunity to investigate the oxidative chemical mechanisms in the presence of high isoprene. At the higher concentrations that were characteristic of the region at the time of SOS and SEAVS in the 1990s, peroxy radical chemistry was dominated by high- $\mathrm{NO}_{x}$ concentrations and was thus insensitive to variations in its concentration (Kleinman et al. 1997). Observations from SAS provided fresh insight into $\mathrm{NO}_{x}$ lifetime as a result of better-characterized production and sinks during day and night.

During SAS, daytime $\mathrm{NO}_{x}$ ranged from 1 to 5 parts per billion (ppb) over cities and $0.015-0.1 \mathrm{ppb}$ in rural areas, and rural concentrations were sufficiently low that less than half of the peroxy radicals formed from VOC oxidation reacted with $\mathrm{NO}_{x}$ (Travis et al. 2016). The atmospheric fate of isoprene nitrates is not yet well understood but was a major research emphasis for SAS (Schwantes et al. 2015). A key issue is the extent to which isoprene (and monoterpene) nitrates resulted in rapid removal of oxidized $\mathrm{N}$ from the reactive pool versus return to the atmosphere as $\mathrm{NO}_{x}$, locally or downwind.

Novel mass spectrometric instruments at CTR measured speciated organic nitrogen in both the particle and gas phases (Lee et al. 2016). These data showed that organic nitrates are highly functionalized in the particle phase and that isoprene- and monoterpenederived organic nitrates have distinct diurnal profiles consistent with their emission profiles, implying that particle-phase organic nitrates are, on average, short lived (2-4 h). A separate study also concluded that organic nitrates had average lifetimes shorter than $2 \mathrm{~h}$, with their hydrolysis accounting for the largest source of $\mathrm{HNO}_{3}$ (Lee et al. 2016; Romer et al. 2016). Production and loss of organic nitrates was the primary control for the lifetime of $\mathrm{NO}_{x}$ at CTR, estimated as $11 \pm 5 \mathrm{~h}$ at midday (Romer et al. 2016). Analysis with the Goddard Earth Observing System global chemical transport model (GEOS-Chem) of ground-based SOAS and aircraft SEAC ${ }^{4} \mathrm{RS}$ data estimated that isoprene nitrates account for $25 \%-50 \%$ of total organic nitrates in surface air, and that aerosol uptake followed by hydrolysis to $\mathrm{HNO}_{3}$ accounts for $60 \%$ of gas-phase organic nitrate loss in the boundary layer in the SEUS (Fisher et al. 2016). A separate study, however, found consistency between chamber measurements of the photochemical yield of isoprene nitrates (9\%) and their observed ratio to other isoprene oxidation products at CTR with no hydrolysis loss (Xiong et al. 2015).

Nighttime BVOC oxidation through the nitrate radical $\mathrm{NO}_{3}$ was a significant focus of SAS. The NOAA WP-3D executed three dedicated night flights as part of SENEX, and there were several analyses from the SOAS ground site of the role of $\mathrm{NO}_{3}-$ monoterpene reactions as an SOA source. Analysis of aerosol composition data suggests that a third of the organic aerosol mass at CTR was attributable to $\mathrm{NO}_{3}$-monoterpene reactions (Xu et al. 2015a). A molar yield of $23 \%-44 \%$ particle-phase monoterpene nitrates from monoterpene oxidation by $\mathrm{NO}_{3}$ was estimated, with little evidence for particle-phase isoprene nitrates (Ayres et al. 2015).

There were also several analyses of inorganic nitrogen chemistry. Particle-phase inorganic nitrate, for example, was found to be associated principally with sea salt and dust as a result of the high acidity of submicron aerosols that precluded the formation of ammonium nitrate (Allen et al. 2015; Guo et al. 2015). Speciated amines partitioned favorably to the particle phase (gas-to-particle amine mass ratio was $\sim 0.01$ ) and comprised approximately $2 \%$ of the sum of particlephase ammonium and amine mass (You et al. 2014). Based on aircraft data from the NSF/NCAR C-130, an upper-limit yield of nitrous acid (HONO) was estimated to be 0.03 for the reaction between $\mathrm{HO}_{2} \cdot \mathrm{H}_{2} \mathrm{O}$ and $\mathrm{NO}_{2}$, too low for the reaction to be an important daytime HONO formation mechanism in the troposphere (Ye et al. 2015). Although not directly relevant to the SEUS, airborne observations over the North Atlantic Ocean as part of the C-130 flights during SAS provided evidence that suggested rapid recycling of $\mathrm{HNO}_{3}$ to $\mathrm{HONO}$ and $\mathrm{NO}_{x}$ in the marine boundary layer via particulate nitrate photolysis (Ye et al. 2016). Laboratory experiments and box model experiments were supportive (Ye et al. 2016). Exploration of this pathway remains a critical open question for continued scientific debate.

Anthropogenic emissions and trends in ambient concentrations. Accurate knowledge of current emissions and trends for reactive trace gases, aerosol, and greenhouse gases in the SEUS is needed to understand atmospheric chemical transformations and predict trends in air quality and climate. Emissions of $\mathrm{NO}_{x}$, $\mathrm{SO}_{2}$, mercury (Hg), and VOCs from major U.S. urban 
areas and power plants have decreased, as evidenced by surface and satellite observations (Hand et al.2013; Warneke et al. 2012), and these emission reductions are evident in the SEUS. During SAS, the NSF/NCAR C-130 and NOAA WP-3D research aircraft quantified emissions from a variety of sources in the SEUS, including urban areas, point sources (power plants, coal mines, animal husbandry, and biofuel refineries), oil and natural gas production, and agricultural burning. These measurements were interpreted in the context of previous intensives and long-termmonitoring datasets to address key science questions:

1) What are the emissions from the main sources in the SEUS?

2) How well do current emission inventories represent these emissions?

3) How have anthropogenic emissions of gases and aerosols $\left(\mathrm{SO}_{2}, \mathrm{NO}_{x}, \mathrm{VOCs}, \mathrm{NH}_{3}, \mathrm{PM}, \mathrm{Hg}\right.$, etc. $)$ recently changed?

4) How have the atmospheric concentrations of primary and secondary pollutants responded to these changes in emissions?

5) What are the implications for air quality and climate in the region?

6) What were the drivers of these emission changes (e.g., emissions changes driven by control programs, source activity changes, or economic shifts)?

Mixing ratios of anthropogenic pollutants have been greatly reduced since the SOS flights in 1999 (Warneke et al. 2016). Mobile source emissions dropped by $59 \%, 49 \%$, and $51 \%$ for $\mathrm{NO}_{x}$, VOC, and $\mathrm{PM}_{2.5}$, respectively, from 1999 to 2013 in a region that included Alabama, Georgia, Mississippi, and northwestern Florida (Hidy et al. 2014). Since SOS, examples for the impacts of power sector emission changes can be seen in $\mathrm{SO}_{2}$ and sulfate mass reductions (de Gouw et al. 2014; Blanchard et al. 2013a; Hand et al. 2012), decreased aerosol optical depth (Attwood et al. 2014), and a potentially controlling effect on SOA mass, as discussed below. GEOS-Chem chemical transport model predictions of $\mathrm{NO}_{x}$ and its oxidation products can be reconciled with observations from the SEAC ${ }^{4} \mathrm{RS}$ campaign only by reducing $\mathrm{NO}_{x}$ emissions by $60 \%$ for all sources except for power plants to reconcile modeled $\mathrm{NO}_{x}$ and its oxidation products with measurements (Travis et al. 2016). $\mathrm{CH}_{4}$ emissions determined by eddy covariance (Yuan et al. 2015) and a regional mass budget (Peischl et al. 2015) from oil and natural gas production showed leak rates of $0.3 \%, 1.6 \%$, and $1.9 \%$ for the Marcellus, Haynesville, and Fayetteville shale gas production regions, respectively. These leak rates were substantially lower than earlier basinwide estimates from Colorado and Utah (Pétron et al. 2012; Karion et al. 2013). De Gouw et al. (2015a) examined ethanol and other trace-gas emissions from a biofuel refinery. While emissions of $\mathrm{SO}_{2}$ and $\mathrm{NO}_{x}$ agreed with emissions reported to the 2011 National Emissions Inventory (NEI-2011), emissions of several VOCs, including ethanol, formaldehyde, and acetaldehyde, were underestimated by an order of magnitude. These discrepancies between observed, reported, and modeled emissions highlight a need for more thorough understanding of emissions models and the design of field studies that isolate specific source sectors.

Mercury. Mercury is a globally distributed bioaccumulative neurotoxin, and there are large uncertainties in the atmospheric processing and global budgets. Understanding the sources and chemistry of atmospheric $\mathrm{Hg}$ was one of the goals of NOMADSS. The $\mathrm{Hg}$-specific goals were to 1) constrain emissions of $\mathrm{Hg}$ from major U.S. source regions, 2) understand the origin of oxidized $\mathrm{Hg}$ in the free troposphere, 3) quantify the distribution of speciated $\mathrm{Hg}$ in the troposphere and compare with global model simulations, and 4) develop a calibration method using $\mathrm{HgBr}_{2}$ for a commercial $\mathrm{Hg}$ instrument at the Birmingham SEARCH site.

$\mathrm{Hg}$ observations on the $\mathrm{C}-130$ made using the Detector for Oxidized Hg Species (DOHGS) (Ambrose et al. 2015) measured both gaseous elemental mercury $\left(\mathrm{Hg}^{0}\right)$ and gaseous oxidized mercury (GOM), plus a fraction of particle-bound oxidized Hg. GOM is believed to consist of $\mathrm{Hg}$ (II) compounds, such as $\mathrm{HgCl}_{2}$ and $\mathrm{HgBr}_{2}$. A key finding was that the NEI-2011 reflected $\mathrm{Hg}$ emission slightly better than the Toxic Release Inventory, but for some large coal-fired power plants (CFPP), total Hg emissions inferred from ambient measurements were higher than the NEI estimates (Ambrose et al. 2015). Gratz et al. (2016) also evaluated $\mathrm{Hg}$ emission inventories, but for the Chicago-Gary metropolitan area. Their observations similarly suggested that the emission inventory is biased low, in part due to underestimated CFPP emissions, and also due to many small sources missing from the inventory.

Because of the importance of $\mathrm{Hg}^{0}$ oxidation in the global Hg cycle, a key NOMADSS goal was to understand the distribution and chemistry of GOM in the atmosphere. For this reason, NOMADSS flights sampled air in the mid- to upper troposphere over the SEUS. In this region, prior studies and NOMADSS forecasts (Shah et al. 2016) suggested the presence of high GOM concentrations. On one NOMADSS flight, 
very high concentrations of $\mathrm{GOM}\left(0.266 \mathrm{ng} \mathrm{m}^{-3}\right)$ were detected and, simultaneously, $\mathrm{BrO}$ was significantly elevated (up to 1.9 parts per trillion by volume). Gratz et al. (2015) used these observations with a chemical box model and found strong support for the formation of $\mathrm{HgBr}_{2}$ (and possibly other GOM compounds) by Br-initiated oxidation. Other mechanisms appeared unable to explain high GOM concentrations. Using the GEOS-Chem chemical transport model, Shah et al. (2016) provided further support for the bromine mechanism and demonstrated that $\mathrm{BrO}$ mixing ratios in the model are likely too low. They further showed that the highest GOM concentrations were predicted to occur in subsiding air in subtropical anticyclones, due to fast production and slow removal. Song et al. (2016) also used the NOMADSS observations with the GEOS-Chem model and suggested the northwestern Atlantic is a net source of $\mathrm{Hg}^{0}$, with large fluxes in summer, likely due to strong wet deposition of $\mathrm{Hg}$ in this region. In contrast, terrestrial ecosystems in the eastern United States during summer are likely a net sink of $\mathrm{Hg}^{0}$. These results are consistent with the constraints on surface-atmosphere cycling of $\mathrm{Hg}$ found using a global suite of observations and an inverse-modeling approach (Song et al. 2015).

Finally, ground-based observations of $\mathrm{Hg}$ provided new insights into our ability to measure $\mathrm{Hg}^{0}$ and GOM using commercially available instrumentation. McClure et al. (2014) installed a novel system to measure total atmospheric mercury and a calibration system for GOM alongside a standard commercial instrument (Tekran Instruments Corporation, Toronto, Canada). The system could measure GOM accurately in zero air but suffered from significant interference at ambient ozone and humidity. This work indicated the need for improved GOM calibration methods and further development of atmospheric Hg instrumentation.

Gas- and multiphase chemical mechanisms. The SAS campaign brought together the latest instrumentation to address the following questions pertaining to gasand multiphase atmospheric chemistry:

1) What are the chemical and physical processes that control the oxidation of BVOCs?

2) How do anthropogenic influences alter the distribution of the BVOC oxidation products, and what are the implications for the formation of ozone, reactive nitrogen, and aerosol?

3) How does aqueous chemistry alter the fate of BVOC oxidation products and the formation of SOA?
Over the last decade, there have been major revisions in the description of the chemical mechanisms that connect the release of alkenes from the biosphere with the formation of oxidants and aerosols. These include 1) discovery of chemically labile epoxide (Paulot et al. 2009a; Lin et al. 2013a) and lactone atmospheric intermediates (T. B. Nguyen et al. 2015b) and their heterogeneous reactions to form SOA (Surratt et al. 2010; Lin et al. 2012; Lin et al. 2013a; T. B. Nguyen et al. 2015b); 2) generation of low-volatility oxygenated hydrocarbons via auto-oxidation (Peeters et al. 2009; Crounse et al. 2013; Ehn et al. 2014); 3) a more complete description of organic nitrate formation and loss (Xie et al. 2013; L. Lee et al. 2014); and 4) recognition of the impact of aqueous phase chemistry on oligomer, organosulfate, and secondary organic aerosol formation (Lin et al. 2014; Gaston et al. 2014; T. B. Nguyen et al. 2014b), connecting back to earlier SEUS studies (Blando and Turpin 2000).

A central design goal of SAS was to make use of state-of-the-art analytical instrumentation to evaluate current chemical mechanisms for accuracy and completeness. Coincident deployment of multiple instruments provided for evaluation of these new techniques while deployment on many platforms, including aircraft, towers, and ground installations, allowed for regional characterization. In some cases, controlled experiments were conducted with ambient air.

The CTR and LRK sites experienced isoprenedominated biogenic emissions, with high coemission of monoterpenes, substantial aerosol liquid water concentrations (T. K. V. Nguyen et al. 2014), low aerosol $\mathrm{pH}$ (Guo et al. 2015), and a range of oxidation conditions implicated in the formation of biogenic aerosol. These surface sites also experienced varying degrees of anthropogenic pollution influence. Both sites are bordered by areas of high and low $\mathrm{NO}_{x}$ concentrations.

Many of the instruments deployed to CTR also participated in the FIXCIT postcampaign laboratory chamber study that simulated daytime and nighttime oxidation of biogenic alkenes under $\mathrm{NO}$ - and $\mathrm{HO}_{2}-$ dominated regimes (T. B. Nguyen et al. 2014a). These experiments provided a key tie between tabulated mechanisms and the field observations. Experiments at FIXCIT also tested for consistency of various instrumentation (e.g., evaluated calibration and interferences for field instrumentation; Rivera-Rios et al. 2014).

Preliminary results from SAS suggest several prominent types of interactions between biogenic organic and anthropogenic $\left(\mathrm{SO}_{2}\right.$ and $\left.\mathrm{NO}_{x}\right)$ emissions, for example, interactions leading to the formation of organonitrates (see previous section) and organosulfates (Budisulistiorini et al. 2015; Boone 
et al. 2015). Oxidation rates for individual VOCs in urban plumes were faster compared to the isoprenedominated background (Kaiser et al. 2015). However, the glyoxal to formaldehyde ratio was not a reliable indicator of anthropogenic versus biogenic VOC mix, contrary to previous suggestions and applications to satellite data (Kaiser et al. 2015). Isoprene epoxydiol-derived SOA (IEPOX-SOA) was correlated with sulfate (coefficient of determination $r^{2}=0.6$; Budisulistiorini et al. 2015; Xu et al. 2015a), and high IEPOX-SOA episodes were associated with westerly (anthropogenically influenced) flows in comparison to flows from the more rural and biogenic south and southeast (Budisulistiorini et al. 2015). Despite laboratory evidence that the rate of IEPOX-SOA formation is faster on acidic sulfate than ammonium sulfate (e.g., Riedel et al. 2016), IEPOX-SOA at LRK did not show a dependence on local $\mathrm{pH}$. It has been postulated that this discrepancy may be because proton activity is not rate limiting in the SEUS or in the IEPOX reaction (T. B. Nguyen et al. 2014b; Xu et al. 2015a). Or perhaps formation occurs regionally and thus is insensitive to local conditions (Lin et al. 2013b). Additionally, although some liquid water is needed for the formation of IEPOX-SOA, the SOA mass was shown to be weakly, and negatively, correlated with aerosol water, consistent with the conflicting effects of higher IEPOX accommodation but lower inorganic ion activity as water increases (Gaston et al. 2014; T. B. Nguyen et al. 2014b). Ambient observations at SAS show poor correlation between IEPOX-SOA and aerosol water, possibly due to differences in the ionic activity of the ambient aerosol water sampled with diurnal and spatial variations. Future mechanism development will benefit from collaborative analyses of the rich array of real-time measurements of intermediate and highly oxidized BVOC products, oxidant species, and emission fluxes and shared scientific objectives.

Organic aerosol budget. A major fraction of fine PM mass worldwide and in the SEUS consists of organic aerosol (OA; e.g., Zhang et al. 2007). Many sources contribute to ambient $\mathrm{OA}$, their relative impacts are poorly understood, and predictions of OA mass by global models can disagree by more than an order of magnitude (Tsigaridis et al. 2014). OA sources are divided into primary (POA), which includes anthropogenic emissions (e.g., vehicles, cooking); biomass-burning sources; and secondary (SOA). SOA forms in the atmosphere from anthropogenic, biogenic, and biomass-burning precursors. The formation of SOA from BVOCs is influenced from anthropogenic pollutants, as discussed above. Globally and in the
SEUS, BVOC emissions far outweigh anthropogenic sources, and most SOA is expected to form from biogenic VOCs (Lewis et al. 2004; Kim et al. 2015). SOA from biomass burning typically imparts a small net increment to OA mass (Cubison et al. 2011).

Many recent and rapid advances in OA- and precursor-measurement techniques were deployed during SAS (e.g., B.-H. Lee et al. 2014; Isaacman et al. 2014; Krechmer et al. 2015, 2016; Lopez-Hilfiker et al. 2016; Martinez et al. 2016), and these studies conclude that SOA from biogenic VOCs indeed made substantial contributions to total OA mass during SAS. The isoprene epoxydiol pathway (IEPOXSOA; Paulot et al. 2009b) contributed about $17 \%$ and $32 \%$ (on average) of the OA at CTR (Xu et al. 2015a; Hu et al. 2015; Isaacman-VanWertz et al. 2016) and LRK (Budisulistiorini et al. 2015), respectively. A larger contribution was observed during warmer SAS periods, suggesting the unusually cool conditions during SAS led to lower IEPOX-SOA compared to typical summers (Marais et al. 2016; Budisulistiorini et al. 2016).

The quantification of IEPOX-SOA just discussed was performed using real-time bulk chemical analyses. Source and mechanism attribution was enhanced through identification of molecular markers identified from the chemical characterization of laboratory-generated SOA. Explicitly measured molecular tracers accounted for $85 \%$ of total IEPOX-SOA (Hu et al. 2015), which represents an unprecedented level of molecular closure between bulk and tracer measurements. Many of these IEPOX-SOA tracers were observed to partition between the gas and particle phases, with a large fraction of those in the particle phase in the form of oligomers or accretion products that decompose during analysis in most instruments (Lin et al. 2014; Lopez-Hilfiker et al. 2016; Hu et al. 2016). Other pathways forming SOA from isoprene via low-NO oxidation were estimated to account for several percent of the OA at CTR and LRK (Krechmer et al. 2015; Marais et al. 2016). SOA from high-NO pathways (T. B. Nguyen et al. 2015b) is thought to be important (Kim et al. 2015); however, molecular tracers were less abundant (Rattanavaraha et al. 2016). Isoprene-derived SOA via glyoxal is also thought to contribute several percent to the total OA in the SEUS summer (Knote et al. 2015; Li et al. 2016). Marais et al. (2016) estimate $3.3 \%$ of reacted isoprene in the SEUS forms SOA through all the pathways.

SOA from monoterpene oxidation was also important during SAS, in particular, by oxidation of the $\mathrm{NO}_{3}$ radical (Xu et al. 2015a; Ayres et al. 2015; 
Lee et al. 2016) and by other oxidants (Kim et al. 2015). Many of these oxidation products were observed to be partitioned between the particle and gas phases (Isaacman-VanWertz et al. 2016). $\mathrm{NO}_{3}$ monoterpene SOA is present during all seasons, in contrast to isoprene-derived SOA, which peaks in the summer (Xu et al. 2015b; Budisulistiorini et al. 2016). The contribution of sesquiterpenes is thought to be smaller, but has not yet been directly quantified for SAS. SOA production in clouds (as opposed to in aqueous aerosols) was limited according to Wagner et al. (2015), who analyzed 74 aircraft vertical profiles in the region and concluded that differences in SOA mass concentrations above and below clouds were not statistically significant.

Past studies showed that SOA in the SEUS correlates well with anthropogenic pollution tracers, suggesting formation of SOA from BVOCs may be controlled by anthropogenic emissions (Weber et al. 2007; Carlton et al. 2010). SAS results shed light on this issue. $\mathrm{NO}_{x}$ from anthropogenic sources (mainly vehicles and power plants) controls the rate of oxidation of BVOCs (de Gouw et al. 2015b) and strongly modulates isoprene and monoterpene $\mathrm{SOA}$ as discussed above. Anthropogenic $\mathrm{SO}_{2}$ emissions (mainly from power plants) control aerosol sulfate, acidity (Guo et al. 2015), and water uptake (Carlton and Turpin 2013; T. K. V. Nguyen et al. 2015) and thus strongly influence IEPOX-SOA formation (Xu et al. 2015a; Budisulistiorini et al. 2015; Marais et al. 2016). Formation of organosulfates is an anthropogenic-biogenic interaction leading to SOA (Surratt et al. 2008) and contributed small fractions to the total OA and sulfate mass (Budisulistiorini et al. 2015; Hettiyadura et al. 2015; Liao et al. 2015; Rattanavaraha et al. 2016).

Overall, SAS results are consistent with the hypothesis that anthropogenic emissions control a major fraction of OA in the SEUS (Carlton et al. 2010; $\mathrm{Xu}$ et al. 2015a; Marais et al. 2016). The dependencies are complex and nonlinear. Modeling studies that incorporate SAS findings, for example, Pye et al. (2015), estimate that a $25 \%$ reduction in $\mathrm{NO}_{x}$ emissions leads to a $9 \%$ reduction in OA in the SEUS and a $25 \%$ reduction in ambient sulfate mass can reduce IEPOX-derived SOA up to 75\% (Budisulistiorini et al. 2017). Marais et al. (2016) estimates that the EPAestimated emission reductions by 2025 (34\% for $\mathrm{NO}_{x}$ and $48 \%$ for $\mathrm{SO}_{2}$ ) will lead to a $36 \%$ reduction in total isoprene $\mathrm{SOA}$, driven primarily by reductions in $\mathrm{SO}_{2}$.

Other sources of OA were also important. The amounts of anthropogenic POA and SOA were estimated to be $9 \%$ and $18 \%$ of the total OA (Kim et al. 2015). These results are consistent with the $18 \%$ fraction of fossil carbon at CTR, since only $50 \%$ of the anthropogenic POA and $70 \%$ of the anthropogenic SOA is fossil (Hayes et al. 2015). Kim et al. (2015) also reported a contribution of $11 \%$ for biomass-burning OA at CTR, consistent with a measurement-based estimate of 10\% (Xu et al. 2015a). Washenfelder et al. (2015) found that biomass burning aerosol dominates organic aerosol absorption (brown carbon; $\mathrm{BrC}$ ) at $\mathrm{CTR}$, although $\mathrm{BrC}$ levels were very low. Budisulistiorini et al. (2016) did not detect a biomass-burning factor at LRK. Aging of OA in the atmosphere blurs the source-specific chemical signatures and makes it difficult to ascertain the sources of some OA (Jimenez et al. 2009; Xu et al. 2015b). Trends measured by long-term networks indicate a decrease in OA mass in the SEUS, and this provides a helpful constraint on sources and effects (Blanchard et al. 2013a,b; Hand et al. 2013; T. K. V. Nguyen et al. 2015; Attwood et al. 2014).

Climate-relevant properties of aerosol. Particles in the atmosphere are an important component of the global climate system through direct interactions with incoming solar radiation and indirectly by acting as cloud condensation nuclei (CCN). CCN impact cloud droplet number and modulate cloud reflectivity, development, and lifetime. There is considerable uncertainty in the magnitude of these climate impacts. The key climate-relevant characteristics of the aerosol-size, concentration, optical properties, and water uptake-are governed by gas- and particle-phase physicochemical processes that may occur after emission, including new particle formation (NPF). The number of CCN is affected primarily by primary aerosol emissions (and the associated size distributions of these primary particles), NPF, the growth of new and primary particles to climaterelevant sizes, and particle hygroscopic properties; these processes are tightly coupled to the production of condensable organic and inorganic gas-phase species from oxidation of biogenic and anthropogenic precursors. The spatial distribution of the key aerosol properties described above must be known to accurately, especially in the vertical, calculate their radiative effects. Calculating these properties globally requires understanding of vertical transport, heterogeneous processing in clouds, variation in oxidative chemistry, and the spatial distribution of relative humidity.

SAS science plans and implementation were guided by overarching scientific questions related to the interaction of aerosols and climate, including the following: 
1) What are the extinction, absorption, and cloudnucleating properties of aerosol produced from anthropogenic and biogenic sources in the SEUS? How do these properties vary over space and time and relate to chemical composition, size distribution, and relative humidity $(\mathrm{RH})$ ?

2) What fraction of organic aerosol is natural versus controllable, and what are the impacts of anthropogenic sources on the regional radiation budget and on cloud properties and lifetime?

3) How do anthropogenic and biogenic emissions impact NPF and the subsequent growth of ultrafine particles to $\mathrm{CCN}$ sizes? How does particle chemical composition affect CCN activity? What are the likely effects on cloud properties, extent, and lifetime?

4) Given that black carbon (BC) is coemitted with other species, will controlling BC sources in the SEUS (e.g., diesel emissions, agricultural burning) have a net warming or cooling radiative effect?

5) How will these findings change in the future as a result of warming and changing anthropogenic emissions?

SAS provided a unique opportunity to study aerosol characteristics and processes related to their interaction with radiation and clouds. Instruments specifically for measuring aerosol optical and cloud-nucleating properties were operated at CTR, LRK, and on the NOAA WP-3D aircraft (Table 1). The ground sites provided detailed information on aerosol optical properties at multiple wavelengths, including spectrally resolved measurements in the near-ultraviolet; measurements of $\mathrm{BC}$ concentration, mass, and coating thickness; and aerosol optical and physical characteristics following humidification and volatilization. The hygroscopic growth of the particles, aerosol liquid water (ALW), and size-dependent cloud-activation potential was determined, along with the water-soluble component of the aerosol. Aerosol volatility and its link to chemical composition and cloud activation potential were also measured. These observations were coupled with a number of detailed aerosol compositional measurements, which link the optical and cloud-nucleating properties of the aerosol with biogenic and anthropogenic precursors and atmospheric gas- and aqueous-phase chemistry.

Aircraft measurements included aerosol optical properties and variation with humidity and thermal volatility. Variation in cloud-nucleating properties of particles as a function of water supersaturation, BC concentration, and the thickness and hygroscopicity of coatings on BC particles was studied. NOAA
WP-3D measurements mapped the spatial variation of climate-relevant aerosol characteristics, especially in the vertical.

During SAS there was little evidence that particulate BrC from BVOC oxidation is a significant contributor to aerosol absorption in the SEUS (Washenfelder et al. 2015). Absorption was associated almost entirely with $\mathrm{BC}$ from combustion; the small amounts of $\mathrm{BrC}$ were mostly associated with biomass burning. ALW played a crucial role in aerosol light scattering, and organic species contributed to ALW at CTR, particularly at night (Guo et al. 2015).

Seasonal Moderate Resolution Imaging Spectroradiometer (MODIS) aerosol optical depth (AOD) over the SEUS changes up to a factor of 4 (summer minus winter), with negligible seasonal differences in surface $\mathrm{PM}_{25}$ mass (Kim et al. 2015). The vertical structure of the daytime planetary boundary layer (PBL) and RH was found to be important for total AOD and radiation budget. Wagner et al. (2015) found that aerosol mass in the transition, or cloud layer, portion of the boundary layer contributed significantly to AOD, but they could not fully account for discrepancies in seasonal AOD cycle remotely sensed by satellites and in situ surface measurements (e.g., Goldstein et al. 2009; Ford and Heald 2013). Brock et al. $(2016 a, b)$ demonstrated AOD was sensitive to the $\mathrm{RH}$ profile, mean particle diameter, and size distribution width and less so to aerosol refractive index and hygroscopicity parameterization (Brock et al. 2016a,b). Diel cycle measurements at CTR showed that organic fraction hygroscopicity exhibited variations with particle diameter and source origin. No positive correlation was found between organic hygroscopicity and oxygen-to-carbon ratio. Aerosol heating through a thermal denuder had little effect on hygroscopicity, even when $30 \%$ of the aerosol mass was volatilized (Cerully et al. 2015). Seasonal differences in PBL (Kim et al. 2015) and spatial and seasonal patterns of ALW (T. K. V. Nguyen et al. 2016) have been suggested as possible explanations for the southeast AOD anomaly. A factor-of-2 difference in GEOS-estimated daily maximum mixed layer height between summer and winter (Kim et al. 2015), coupled with different column-integrated summer and winter optical depth-ALW relationships (T. K. V. Nguyen et al. 2016), suggests differences in both ALW and PBL depth both contribute to explain the observed AOD seasonality that helped motivate the SAS study.

FUTURE DIRECTIONS. For a study this large in scope and ambition, it is crucial to collectively 
analyze findings and ensure an integrative process among the entire atmospheric science community. Air quality trends and the SEUS warming hole provide excellent context for broad coordinated study among the different atmospheric communities, and SAS provides a high-quality dataset for sophisticated data mining techniques that can cost-effectively facilitate advances in science (National Academies of Sciences, Engineering, and Medicine 2016). The large SAS dataset, now open to the public and accessible through links listed in Table 1, provides valuable observational constraints for uncertain model parameters and processes (Mao et al. 2016). Like the field campaign, modeling experiments going forward should be coordinated around critical open questions, such as the following:

- What are the relative roles of anthropogenic and uncontrollable near-term climate forcers and large-scale dynamics on temperature trends in the SEUS?

- Does the warming hole persist, is it influenced by human activity, and is the region now warming consistently with global trends?

- Can associations between atmospheric trace species be linked to emission changes and policy choices?

SAS findings improve characterization of climaterelevant properties of aerosol in the SEUS, and this informs the climate research community. It should now be possible to better link trace species to their potential climate effects. Reconciling model discrepancies related to emissions, chemical pathways, and local- and large-scale dynamics is necessary to move forward. Continued coordinated study through data analysis, model development, and application among the different subsets of the atmospheric sciences community, in particular climate researchers, is key to determine the most effective strategies to manage air quality in a changing global climate.

ACKNOWLEDGMENTS. This work was supported by NSF Grants 1242155 (Ann Marie Carlton), 1240611 (Dephine Farmer), 1250569 (Allen H. Goldstein), 1243354 (Jose L. Jimenez,), 1240604 (Paul O. Wennberg), 1216166 (Xianling Zhou), 1215712 (Jochen Stutz), 1217010 (Daniel A. Jaffe), and 1216707 (Noelle Selin); U.S. EPA Grants R83540401 (Jason Surratt), R83540701 (John Mak), R835410 (Anthanasios Nenes), R83541201 (Barbara J. Turpin), and R83587701 (Paul B. Shepson); and NOAA's Health of the Atmosphere and Atmospheric Chemistry, Carbon Cycle, and Climate Programs. Additional funding for the Southeast
Atmosphere Studies was provided through NSF Grants 1246918 (William Brune, Penn State), 1242258 (Rodney Weber, George Tech), 1242932 (Don Collins, Texas A\&M), 1242935 (Rob Griffin, Rice University), 1243356 (Doug Worsnop, Aerodyne Research Inc.), 1247421 (Frank Keutsch, Harvard), 1318307 (Jesse Kroll, MIT), 1241498 (Shanhu Lee, Kent State), and 1216743 (Christopher Cantrell, University of Colorado Boulder). This article was developed under an Assistance Agreement awarded by the U.S. Environmental Protection Agency. It has not been formally reviewed by the EPA. The views expressed in this document are solely those of the authors and do not necessarily reflect those of the agency. EPA does not endorse any products or commercial services mentioned in this publication.

\section{REFERENCES}

Allen, H. M., and Coauthors, 2015: Influence of crustal dust and sea spray supermicron particle concentrations and acidity on inorganic $\mathrm{NO}_{3}^{-}$aerosol during the 2013 Southern Oxidant and Aerosol Study. Atmos. Chem. Phys., 15, 10669-10 685, https://doi .org/10.5194/acp-15-10669-2015.

Ambrose, J. L., and Coauthors, 2015: Mercury emission ratios from coal-fired power plants in the southeastern United States during NOMADSS. Environ. Sci. Technol., 49, 10389-10 397, https://doi.org/10.1021 /acs.est.5b01755.

Andrews, E., P. Saxena, S. Musarra, L. M. Hildemann, P. Koutrakis, P. H. McMurry, I. Olmez, and W. H. White, 2000: Concentration and composition of atmospheric aerosols from the 1995 SEAVS experiment and a review of the closure between chemical and gravimetric measurements. J. Air Waste Manage. Assoc., 50, 648-664, https://doi.org/10.1080/10473289 .2000 .10464116 .

ARA, 2016: Introduction to the SouthEastern Aerosol Research and Characterization (SEARCH) Network. Atmospheric Research Analysis, accessed 5 June 2016, www.atmospheric-research.com/studies /SEARCH/.

Attwood, A. R., and Coauthors, 2014: Trends in sulfate and organic aerosol mass in the Southeast U.S.: Impact on visibility and aerosol optical depth. Geophys. Res. Lett., 41, 7701-7709, https://doi.org /10.1002/2014GL061669.

Ayres, B. R., and Coauthors, 2015: Organic nitrate aerosol formation via $\mathrm{NO}_{3}+$ biogenic volatile organic compounds in the southeastern United States. Atmos. Chem. Phys., 15, 13377-13392, https://doi .org/10.5194/acp-15-13377-2015.

Banerjee, A., L. M. Polvani, and J. C. Fyfe, 2017: The United States “warming hole”: Quantifying the 
forced aerosol response given large internal variability. Geophys. Res. Lett., 44, 1928-1937, https:// doi.org/10.1002/2016GL071567.

Blanchard, C. L., G. M. Hidy, S. Tanenbaum, E. S. Edgerton, and B. E. Hartsell, 2013a: The Southeastern Aerosol Research and Characterization (SEARCH) study: Temporal trends in gas and PM concentrations and composition, 1999-2010. J. Air Waste Manage. Assoc., 63, 247-259, https://doi.org/10.1080/10962247 .2012.748523.

— , S. Tanenbaum, and G. M. Hidy, 2013b: Source attribution of air pollutant concentrations and trends in the Southeastern Aerosol Research and Characterization (SEARCH) Network. Environ. Sci. Technol., 47, 13 536-13 545, https://doi.org/10.1021/es402876s. —, G. M. Hidy, S. Shaw, K. Baumann, and E. S. Edgerton, 2016: Effects of emission reductions on organic aerosol in the southeastern United States. Atmos. Chem. Phys., 16, 215-238, https://doi .org/10.5194/acp-16-215-2016.

Blando, J. D., and B. J. Turpin, 2000: Secondary organic aerosol formation in cloud and fog droplets: A literature evaluation of plausibility. Atmos. Environ., 34, 1623-1632, https://doi.org/10.1016/S1352 $-2310(99) 00392-1$.

Boone, E. J., A. Lasin, J. Laskin, C. Wirth, P. B. Shepson, B. H. Strim, and K. A. Pratt, 2015: Aqueous processing of atmospheric organic particles in cloud water collected via aircraft sampling. Atmos. Chem. Phys., 49, 8523-8530, https://doi.org/10.1021/acs .est.5b01639.

Brock, C. A., and Coauthors, 2016a: Aerosol optical properties in the southeastern United States in summer - Part 1: Hygroscopic growth. Atmos. Chem. Phys., 16, 4987-5007, https://doi.org/10.5194/acp -16-4987-2016.

— in the southeastern United States in summer - Part 2: Sensitivity of aerosol optical depth to relative humidity and aerosol parameters. Atmos. Chem. Phys., 16, 5009-5019, https://doi.org/10.5194/acp -16-5009-2016.

Budisulistiorini, S. H., and Coauthors, 2015: Examining the effects of anthropogenic emissions on isoprene-derived secondary organic aerosol formation during the 2013 Southern Oxidant and Aerosol Study (SOAS) at the Look Rock, Tennessee ground site. Atmos. Chem. Phys., 15, 8871-8888, https://doi .org/10.5194/acp-15-8871-2015.

_ , and Coauthors, 2016: Seasonal characterization of submicron aerosol chemical composition and organic aerosol sources in the southeastern United States: Atlanta, Georgia, and Look Rock, Tennessee.
Atmos. Chem. Phys., 16, 5171-5189, https://doi .org/10.5194/acp-16-5171-2016.

- A. Nenes, A. G. Carlton, J. D. Surratt, V. F. McNeill, and H. O. T. Pye, 2017: Simulating aqueous-phase isoprene-epoxydiol (IEPOX) secondary organic aerosol production during the 2013 Southern Oxidant and Aerosol Study (SOAS). Environ. Sci. Technol., 51, 5026-5034, https://doi.org/10.1021/acs.est.6b05750.

Carlton, A. G., and B. J. Turpin, 2013: Particle partitioning potential of organic compounds is highest in the eastern US and driven by anthropogenic water. Atmos. Chem. Phys., 13, $10203-10214$, https://doi .org/10.5194/acp-13-10203-2013.

— , R. W. Pinder, P. V. Bhave, and G. A. Pouliot, 2010: To what extent can biogenic SOA be controlled? Environ. Sci. Technol., 44, 3376-3380, https://doi .org/10.1021/es903506b.

— , and Coauthors, 2011: The Southern Oxidant and Aerosol Study (SOAS): Measuring and modeling at the interface of air quality and climate change to understand biosphere-atmosphere interactions. White Paper, 19 pp., http://climate.envsci.rutgers .edu/SOAS/SOAS_White_Paper_final.pdf.

Cerully, K. M., A. Bougiatioti, J. R. Hite Jr., H. Guo, L. $\mathrm{Xu}, \mathrm{N}$. L. Ng, R. Weber, and A. Nenes, 2015: On the link between hygroscopicity, volatility, and oxidation state of ambient and water-soluble aerosols in the southeastern United States. Atmos. Chem. Phys., 15, 8679-8694, https://doi.org/10.5194/acp-15-8679-2015. Chameides, W. L., R. W. Lindsay, J. Richardson, and C. S. Kiang, 1988: The role of biogenic hydrocarbons in urban photochemical smog: Atlanta as a case study. Science, 241, 1473-1475, https://doi.org/10.1126 /science.3420404.

Crounse, J. D., L. B. Nielsen, S. Jorgensen, H. G. Kjaergaard, and P. O. Wennberg, 2013: Autoxidation of organic compounds in the atmosphere. J. Phys. Chem. Lett., 4, 3513-3520, https://doi.org/10.1021 /jz4019207.

Cubison, M. J., and Coauthors, 2011: Effects of aging on organic aerosol from open biomass burning smoke in aircraft and laboratory studies. Atmos. Chem. Phys., 11, 12 049-12 064, https://doi.org/10.5194 /acp-11-12049-2011.

de Gouw, J. A., D. D. Parrish, G. J. Frost, and M. Trainer, 2014: Reduced emissions of $\mathrm{CO}_{2}, \mathrm{NO}_{\mathrm{x}}$, and $\mathrm{SO}_{2}$ from US power plants owing to switch from coal to natural gas with combined cycle technology. Earth's Future, 2, 75-82, https://doi.org/10.1002/2013EF000196.

_ , and Coauthors, 2015a: Airborne measurements of the atmospheric emissions from a fuel ethanol refinery. J. Geophys. Res. Atmos., 120, 4385-4397, https://doi.org/10.1002/2015JD023138. 
- and Coauthors, 2015b: Enhanced removal of biogenic hydrocarbons in power plant plumes constrains the dependence of atmospheric hydroxyl concentrations of nitrogen oxides. 2015 Fall Meeting, San Francisco, CA, Amer. Geophys. Union, Abstract A13G-08.

Ehn, M., and Coauthors, 2014: A large source of lowvolatility secondary organic aerosol. Nature, 506, 476-479, https://doi.org/10.1038/nature13032.

Farkas, C. M., M. D. Moeller, F. A. Felder, K. R. Baker, M. Rodgers, and A. G. Carlton, 2015: Temporalization of peak electric generation particulate matter emissions during high energy demand days. Environ. Sci. Technol., 49, 4696-4704, https://doi.org/10.1021 les5050248.

Fisher, J. A., and Coauthors, 2016: Organic nitrate chemistry and its implications for nitrogen budgets in an isoprene- and monoterpene-rich atmosphere: Constraints from aircraft (SEAC $\left.{ }^{4} \mathrm{RS}\right)$ and ground-based (SOAS) observations in the southeast US. Atmos. Chem. Phys., 16, 5969-5991, https://doi.org/10.5194 /acp-16-5969-2016.

Ford, B., and C. L. Heald, 2013: Aerosol loading in the southeastern United States: Reconciling surface and satellite observations. Atmos. Chem. Phys., 13, 92699283, https://doi.org/10.5194/acp-13-9269-2013.

Gaston, C. J., T. P. Riedel, Z. Zhang, A. Gold, J. D. Surratt, and J. A. Thornton, 2014: Reactive uptake of an isoprene-derived epoxydiol to submicron aerosol particles. Environ. Sci. Technol., 48, 11 178-11 186, https://doi.org/10.1021/es5034266.

Gilliland, A. B., C. Hogrefe, R. W. Pinder, J. M. Godowitch, K. L. Foley, and S. T. Rao, 2008: Dynamic evaluation of regional air quality models: Assessing changes in $\mathrm{O}_{3}$ stemming from changes in emissions and meteorology. Atmos. Environ., 42, 5110-5123, https://doi.org/10.1016/j.atmosenv.2008 .02 .018

Goldstein, A. H., C. D. Koven, C. L. Heald, and I. Y. Fung, 2009: Biogenic carbon and anthropogenic pollutants combine to form a cooling haze over the southeastern United States. Proc. Natl. Acad. Sci. USA, 106, 8835-8840, https://doi.org/10.1073 /pnas.0904128106.

Gratz, L. E., and Coauthors, 2015: Oxidation of mercury by bromine in the subtropical Pacific free troposphere. Geophys. Res. Lett., 42, 10 494-10 502, https:// doi.org/10.1002/2015GL066645.

— and Coauthors, 2016: Airborne observations of mercury emissions from the Chicago/Gary urban/ industrial area during the 2013 NOMADSS campaign. Atmos. Environ., 145, 415-423, https://doi .org/10.1016/j.atmosenv.2016.09.051.
Guenther, A., and Coauthors, 1996: Estimates of regional natural volatile organic compound fluxes from enclosure and ambient measurements. J. Geophys. Res., 101, 1345-1359, https://doi.org/10.1029/95JD03006.

Guo, H., and Coauthors, 2015: Fine-particle water and $\mathrm{pH}$ in the southeastern United States. Atmos. Chem. Phys., 15, 5211-5228, https://doi.org/10.5194/acp -15-5211-2015.

Hand, J. L., B. A. Schichtel, W. C. Malm, and M. L. Pitchford, 2012: Particulate sulfate ion concentration and $\mathrm{SO}_{2}$ emission trends in the United States from the early 1990s through 2010. Atmos. Chem. Phys., 12, 10 353-10 365, https://doi.org/10.5194 /acp-12-10353-2012.

,,--- , and N. H. Frank, 2013: Spatial and temporal trends in $\mathrm{PM}_{2.5}$ organic and elemental carbon across the United States. Adv. Meteor., 2013, 367674, https://doi.org/10.1155/2013/367674.

Hayes, P. L., and Coauthors, 2015: Modeling the formation and aging of secondary organic aerosols in Los Angeles during CalNex 2010. Atmos. Chem. Phys., 15, 5773-5801, https://doi.org/10.5194/acp-15-5773-2015.

Hettiyadura, A. P. S., E. A. Stone, S. Kundu, Z. Baker, E. Geddes, K. Richards, and T. Humphry, 2015: Determination of atmospheric organosulfates using HILIC chromatography with MS detection. Atmos. Meas. Tech., 8, 2347-2358, https://doi.org/10.5194 /amt-8-2347-2015.

Hidy, G. M., and Coauthors, 2014: Chemical climatology of the southeastern United States, 1999-2013. Atmos. Chem. Phys., 14, 11 893-11 914, https://doi .org/10.5194/acp-14-11893-2014.

Holben, B. N., and Coauthors, 1998: AERONET-A federated instrument network and data archive for aerosol characterization. Remote Sens. Environ., 66, 1-16, https://doi.org/10.1016/S0034-4257(98)00031-5.

$\mathrm{Hu}, \mathrm{W}$. W., and Coauthors, 2015: Characterization of a real-time tracer for isoprene epoxydiols-derived secondary organic aerosol (IEPOX-SOA) from aerosol mass spectrometer measurements. Atmos. Chem. Phys., 15, 11 807-11 833, https://doi.org/10.5194 /acp-15-11807-2015.

_- and Coauthors, 2016: Volatility and lifetime against $\mathrm{OH}$ heterogeneous reaction of ambient isopreneepoxydiols-derived secondary organic aerosol (IEPOX-SOA). Atmos. Chem. Phys., 16, 11563-11580, https://doi.org/10.5194/acp-16-11563-2016.

IMPROVE, 2016: Interagency Monitoring of Protected Visual Environments. Accessed 5 June 2016, http:// vista.cira.colostate.edu/improve/.

IPCC, 2013: Climate Change 2013: The Physical Science Basis. Cambridge University Press, 1535 pp., https:// doi.org/10.1017/CBO9781107415324. 
— , 2014: Climate Change 2014: Impacts, Adaptation, and Vulnerability. Part A: Global and Sectoral Aspects. Cambridge University Press, 1132 pp., https://doi.org/10.1017/CBO9781107415379.

IRAC, 2013: Outdoor air pollution a leading environmental cause of cancer deaths. WMO Press Release 221, 4 pp., www.iarc.fr/en/media-centre /iarcnews/pdf/pr221_E.pdf.

Isaacman, G., N. M. Kriesberg, L. D. Yee, D. R. Worton, A. W. Chan, J. A. Moss, S. V. Hering, and A. H. Goldstein, 2014: Online derivatization for hourly measurements of gas- and particle-phase semivolatile oxygenated organic compound by thermal desorption aerosol gas chromatography (SV-TAG). Atmos. Meas. Tech., 7, 4417-4429, https://doi .org/10.5194/amt-7-4417-2014.

Isaacman-VanWertz, G., and Coauthors, 2016: Ambient gas-particle partitioning of tracers for biogenic oxidation. Environ. Sci. Technol., 50, 9952-9962, https:// doi.org/10.1021/acs.est.6b01674.

Jacob, D. J., and D. A. Winner, 2009: Effect of climate change on air quality. Atmos. Environ., 43, 51-63, https://doi.org/10.1016/j.atmosenv.2008.09.051.

Jimenez, J. L., and Coauthors, 2009: Evolution of organic aerosols in the atmosphere. Science, 326, 1525-1529, https://doi.org/10.1126/science.1180353.

Kaiser, J., and Coauthors, 2015: Reassessing the ratio of glyoxal to formaldehyde as an indicator of hydrocarbon precursor speciation. Atmos. Chem. Phys., 15, 7571-7583, https://doi.org/10.5194/acp $-15-7571-2015$.

Karion, A., and Coauthors, 2013: Methane emissions estimate from airborne measurements over a western United States natural gas field. Geophys. Res. Lett., 40, 4393-4397, https://doi.org/10.1002/grl.50811.

Kaser, L., and Coauthors, 2015: Chemistry-turbulence interactions and mesoscale variability influence the cleansing efficiency of the atmosphere. Geophys. Res. Lett., 42, 10 894-10 903, https://doi .org/10.1002/2015GL066641.

Kim, P. S., and Coauthors, 2015: Sources, seasonality, and trends of southeast US aerosol: An integrated analysis of surface, aircraft, and satellite observations with the GEOS-Chem chemical transport model. Atmos. Chem. Phys., 15, 10411-10433, https://doi .org/10.5194/acp-15-10411-2015.

Kleinman, L. I., and Coauthors, 1997: Dependence of ozone production on $\mathrm{NO}$ and hydrocarbons in the troposphere. Geophys. Res. Lett., 24, 2299-2302, https://doi.org/10.1029/97GL02279.

Knote, C., A. Hodzic, and J. L. Jimenez, 2015: The effect of dry and wet deposition of condensable vapors on secondary organic aerosol concentrations over the continental U.S. Atmos. Chem. Phys., 15, 1-18, https://doi.org/10.5194/acp-15-1-2015.

Krechmer, J. E., and Coauthors, 2015: Formation of low volatility organic compounds and secondary organic aerosol from isoprene hydroxyhydroperoxide low-NO oxidation. Environ. Sci. Technol., 49, $10330-$ 10339, https://doi.org/10.1021/acs.est.5b02031.

— , and Coauthors, 2016: Ion mobility spectrometry-mass spectrometry (IMS-MS) for on- and offline analysis of atmospheric gas and aerosol species. Atmos. Meas. Tech., 9, 3245-3262, https:// doi.org/10.5194/amt-9-3245-2016.

Kunkel, K. E., X.-Z. Liang, J. Zhu, and Y. Lin, 2006: Can CGCMs simulate the twentieth-century "warming hole" in the central United States? J. Climate, 19, 4137-4153, https://doi.org/10.1175/JCLI3848.1.

Lee, B. H., F. D. Lopez-Hilfiker, C. Mohr, T. Kurtén, D. R. Worsnop II, and J. A. Thronton, 2014: An iodideadduct high-resolution time-of-flight chemicalionization mass spectrometer: Application to atmospheric inorganic and organic compounds. Environ. Sci. Technol., 48, 6309-6317, https://doi.org/10.1021 les500362a.

— organic nitrates in the southeast United States: Contribution to secondary organic aerosol and reactive nitrogen budgets. Proc. Natl. Acad. Sci. USA, 113, 1516-1521, https://doi.org/10.1073/pnas .1508108113 .

Lee, L., A. P. Teng, P. O. Wennberg, J. D. Crounse, and R. C. Cohen, 2014: On rates and mechanisms of $\mathrm{OH}$ and $\mathrm{O}_{3}$ reactions with isoprene-derived hydroxy nitrates. J. Phys. Chem., 118A, 1622-1637, https://doi .org/10.1021/jp4107603.

Leibensperger, E. M., and Coauthors, 2012: Climatic effects of 1950-2050 changes in US anthropogenic aerosols - Part 2: Climate response. Atmos. Chem. Phys., 12, 3349-3362, https://doi.org/10.5194/acp $-12-3349-2012$.

Lewis, C. W., G. A. Klouda, and W. D. Ellenson, 2004: Radiocarbon measurement of the biogenic contribution to summertime PM2.5 ambient aerosol in Nashville, TN. Atmos. Environ., 38, 6053-6061, https://doi.org/10.1016/j.atmosenv.2004.06.011.

Li, J. Y., and Coauthors, 2016: Observational constraints on glyoxal production from isoprene oxidation and its contribution to organic aerosol over the Southeast United States. J. Geophys. Res. Atmos., 121, 9849-9861, https://doi.org/10.1002 /2016JD025331.

Liang, X.-Z., J. Pan, J. Zhu, K. E. Kunkel, J. X. L. Wang, and A. Dai, 2006: Regional climate model downscaling of the U.S. summer climate and future 
change. J. Geophys. Res., 111, D10108, https://doi .org/10.1029/2005JD006685.

Liao, J., and Coauthors, 2015: Airborne organosulfates measurements over the continental U.S. J. Geophys. Res. Atmos., 120, 2990-3005, https://doi .org/10.1002/2014JD022378.

Lin, Y.-H., and Coauthors, 2012: Isoprene epoxydiols as precursors to secondary organic aerosol formation: Acid-catalyzed reactive uptake studies with authentic compounds. Environ. Sci. Technol., 46, 250-258, https://doi.org/10.1021/es202554c.

— secondary organic aerosol formation from isoprene photooxidation in the presence of nitrogen oxides. Proc. Natl. Acad. Sci. USA, 110, 6718-6723, https:// doi.org/10.1073/pnas.1221150110.

—, E. M. Knipping, E. S. Edgerton, S. L. Shaw, and J. D. Surratt, 2013b: Investigating the influences of $\mathrm{SO}_{2}$ and $\mathrm{NH}_{3}$ levels on isoprene-derived secondary organic aerosol formation using conditional sampling approaches. Atmos. Chem. Phys., 13, 84578470, https://doi.org/10.5194/acp-13-8457-2013.

— - and Coauthors, 2014: Light-absorbing oligomer formation in secondary organic aerosol from reactive uptake of isoprene epoxydiols. Environ. Sci. Technol., 48, 12 012-12 021, https://doi.org/10.1021 les503142b.

Lopez-Hilfiker, F. D., and Coauthors, 2016: Molecular composition and volatility of organic aerosol in the Southeastern U.S.: Implications for IEPOX derived SOA. Environ. Sci. Technol., 50, 2200-2209, https:// doi.org/10.1021/acs.est.5b04769.

Mao, J., and Coauthors, 2016: Southeast Atmosphere Studies: Learning from model-observation syntheses. Atmos. Chem. Phys. Discuss., https://doi .org/10.5194/acp-2016-1063.

Marais, E. A., and Coauthors, 2016: Aqueous-phase mechanism for secondary organic aerosol formation from isoprene: Application to the southeast United States and co-benefit of $\mathrm{SO}_{2}$ emission controls. Atmos. Chem. Phys., 16, 1603-1618, https://doi .org/10.5194/acp-16-1603-2016.

Martin, R. V., 2008: Satellite remote sensing of surface air quality. Atmos. Environ., 42, 7823-7843, https:// doi.org/10.1016/j.atmosenv.2008.07.018.

Martinez, R. E., and Coauthors, 2016: Development of a volatility and polarity separator (VAPS) for volatilityand polarity-resolved organic aerosol measurement. Aerosol Sci. Technol., 50, 255-271, https://doi.org/10 $.1080 / 02786826.2016 .1147645$.

McClure, C. D., D. A. Jaffe, and E. S. Edgerton, 2014: Evaluation of the $\mathrm{KCl}$ denuder method for gaseous oxidized mercury using $\mathrm{HgBr}_{2}$ at an in-service
AMNet site. Environ. Sci. Technol., 48, 11 437-11444, https://doi.org/10.1021/es502545k.

Meehl, G. A., J. M. Arblaster, and G. Branstator, 2012: Mechanisms contributing to the warming hole and the consequent U.S. east-west differential of heat extremes. J. Climate, 25, 6394-6408, https://doi .org/10.1175/JCLI-D-11-00655.1.

National Academies of Sciences, Engineering, and Medicine, 2016: The Future of Atmospheric Chemistry Research: Remembering Yesterday, Understanding Today, Anticipating Tomorrow. National Academies Press, 240 pp., https://doi.org /10.17226/23573.

NCSU, 2006: The Southern Oxidant Study. North Carolina State University, accessed 5 June 2016, www .ncsu.edu/sos/.

Nguyen, T. B., and Coauthors, 2014a: Overview of the Focused Isoprene eXperiment at the Callifornia Institute of Technology (FIXCIT): Mechanistic chamber studies on the oxidation of biogenic compounds. Atmos. Chem. Phys., 14, 13 531-13 549, https://doi.org/10.5194/acp-14-13531-2014.

_ , and Coauthors, 2014b: Organic aerosol formation from the reactive uptake of isoprene epoxydiols (IEPOX) onto non-acidified inorganic seeds. Atmos. Chem. Phys., 14, 3497-3510, https://doi.org/10.5194 /acp-14-3497-2014.

—, J. D. Crounse, A. P. Teng, J. M. St. Clair, F. Paulot, G. M. Wolfe, and P. O. Wennberg, 2015a: Rapid deposition of oxidized biogenic compounds to a temperate forest. Proc. Natl. Acad. Sci. USA, 112, E392-E401, https://doi.org/10.1073/pnas.1418702112.

— droxyl radical oxidation of methacryoyl peroxynitrate (MPAN) and its pathway toward secondary organic aerosol formation in the atmosphere. Phys. Chem. Chem. Phys., 17, 17 914-17 926, https://doi .org/10.1039/C5CP02001H.

— and Coauthors, 2016: Atmospheric fates of Criegee intermediates in the ozonolysis of isoprene. Phys. Chem. Chem. Phys., 18, $10241-10254$, https://doi .org/10.1039/C6CP00053C.

Nguyen, T. K. V., M. D. Petters, S. R. Suda, H. Guo, R. J. Weber, and A. G. Carlton, 2014: Trends in particlephase liquid water during the Southern Oxidant and Aerosol Study. Atmos. Chem. Phys., 14, 10 911-10 930, https://doi.org/10.5194/acp-14-10911-2014.

—, S. L. Capps, and A. G. Carlton, 2015: Decreasing aerosol water is consistent with OC trends in the southeast U.S. Environ. Sci. Technol., 49, 7843-7850, https://doi.org/10.1021/acs.est.5b00828.

—, V. P. Ghate, and A. G. Carlton, 2016: Reconciling satellite aerosol optical thickness and surface 
fine particle mass through aerosol liquid water. Geophys. Res. Lett., 43, $11903-11$ 912, https://doi .org/10.1002/2016GL070994.

Pan, Z., R. W. Arritt, E. S. Takle, W. J. Gutowski, C. J. Anderson, and M. Segal, 2004: Altered hydrologic feedback in a warming climate introduces a "warming hole." Geophys. Res. Lett., 31, L17109, https://doi.org/10.1029/2004GL020528.

—, X. Liu, S. Kumar, Z. Gao, and J. Kinter, 2013: Intermodel variability and mechanism attribution of central and southeastern U.S. anomalous cooling in the twentieth century as simulated by CMIP5 models. J. Climate, 26, 6215-6237, https://doi .org/10.1175/JCLI-D-12-00559.1.

Paulot, F., J. D. Crounse, H. G. Kjaergaard, J. H. Kroll, J. H. Seinfeld, and P. O. Wennberg, 2009a: Isoprene photooxidation: New insights into the production of acids and organic nitrates. Atmos. Chem. Phys., 9, 1479-1501, https://doi.org/10.5194/acp-9-1479 -2009 .

,,,--- A. Kurten, J. M. St. Clair, J. H. Seinfeld, and P. O. Wennberg, 2009b: Unexpected epoxide formation in the gas-phase photooxidation of isoprene. Science, 325, 730-733, https://doi.org/10.1126/science .1172910 .

Peeters, J., T. L. Nguyen, and L. Vereecken, 2009: HOx radical regeneration in the oxidation of isoprene. Phys. Chem. Chem. Phys., 11, 5935-5939, https://doi .org/10.1039/b908511d.

Peischl, J., and Coauthors, 2015: Quantifying atmospheric methane emissions from the Haynesville, Fayetteville, and northeastern Marcellus shale gas production regions. J. Geophys. Res. Atmos., 120, 2119-2139, https://doi.org/10.1002/2014JD022697.

Pétron, G., and Coauthors, 2012: Hydrocarbon emissions characterization in the Colorado Front Range: A pilot study. J. Geophys. Res., 117, D04304, https:// doi.org/10.1029/2011JD016360.

Portmann, R. W., S. Solomon, and G. C. Hegerl, 2009: Spatial and seasonal patterns in climate change, temperatures, and precipitation across the United States. Proc. Natl. Acad. Sci. USA, 106, 7324-7329, https://doi.org/10.1073/pnas.0808533106.

Pye, H. O. T., and Coauthors, 2015: Modeling the current and future roles of particulate organic nitrates in the southeastern United States. Environ. Sci. Technol., 49, 14 195-14 203, https://doi.org/10.1021/acs.est $.5 \mathrm{~b} 03738$.

Rattanavaraha, W., and Coauthors, 2016: Assessing the impact of anthropogenic pollution on isoprenederived secondary organic aerosol formation in $\mathrm{PM}_{2.5}$ collected from the Birmingham, Alabama, ground site during the 2013 Southern Oxidant and Aerosol
Study. Atmos. Chem. Phys., 16, 4897-4914, https:// doi.org/10.5194/acp-16-4897-2016.

Riedel, T. P., Y.-H. Lin, Z. Zhang, K. Chu, J. A. Thornton, W. Vizuete, A. Gold, and J. D. Surratt, 2016: Constraining condensed-phase formation kinetics of secondary organic aerosol components from isoprene epoxydiols. Atmos. Chem. Phys., 16, 1245-1254, https://doi.org/10.5194/acp-16-1245-2016.

Rivera-Rios, J. C., and Coauthors, 2014: Conversion of hydroperoxides to carbonyls in the field and laboratory instrumentation: Observational bias in diagnosing pristine versus anthropogenically controlled atmospheric chemistry. Geophys. Res. Lett., 41, 8645-8651, https://doi.org/10.1002/2014GL061919.

Robinson, W. A., R. Reudy, and J. E. Hansen, 2002: General circulation model simulations of recent cooling in the east-central United States. J. Geophys. Res., 107, 4748, https://doi.org/10.1029/2001JD001577.

Romer, P. S., and Coauthors, 2016: The lifetime of nitrogen oxides in an isoprene-dominated forest. Atmos. Chem. Phys., 16, 7623-7637, https://doi.org/10.5194 /acp-16-7623-2016.

Schwantes, R. H., and Coauthors, 2015: Isoprene $\mathrm{NO}_{3}$ oxidation products from the $\mathrm{RO}_{2}+\mathrm{HO}_{2}$ pathway. J. Phys. Chem., 119A, $10158-10$ 171, https://doi .org/10.1021/acs.jpca.5b06355.

Shah, V., and Coauthors, 2016: Origin of oxidized mercury in the summertime free troposphere over the southeastern US. Atmos. Chem. Phys., 16, 1511-1530, https://doi.org/10.5194/acp-16-1511-2016.

Song, S., and Coauthors, 2015: Top-down constraints on atmospheric mercury emissions and implications for global biogeochemical cycling. Atmos. Chem. Phys., 15, 7103-7125, https://doi.org/10.5194/acp -15-7103-2015.

— , and Coauthors, 2016: Constraints from observations and modeling on atmosphere-surface exchange of mercury in eastern North America. Elementa: Sci. Anthropocene, 4, 000100, https://doi.org/10.12952 /journal.elementa.000100.

Su, L., and Coauthors, 2016: Understanding isoprene photooxidation using observations and modeling over a subtropical forest in the southeastern US. Atmos. Chem. Phys., 16, 7725-7741, https://doi.org /10.5194/acp-16-7725-2016.

Surratt, J. D., and Coauthors, 2008: Organosulfate formation in biogenic secondary organic aerosol. J. Phys. Chem., 112A, 8345-8378, https://doi.org/10.1021 /jp802310p.

_- and Coauthors, 2010: Reactive intermediates revealed in secondary organic aerosol formation from isoprene. Proc. Natl. Acad. Sci. USA, 107, 6640-6645, https://doi.org/10.1073/pnas.0911114107. 
Toon, O. B., and Coauthors, 2016: Planning, implementation, and scientific goals of the Studies of Emissions and Atmospheric Composition, Clouds and Climate Coupling by Regional Surveys (SEAC ${ }^{4} \mathrm{RS}$ ) field mission. J. Geophys. Res. Atmos., 121, 4967-5009, https://doi.org/10.1002/2015JD024297.

Travis, K. R., and Coauthors, 2016: Why do models overestimate surface ozone in the Southeast United States? Atmos. Chem. Phys., 16, 13561-13 577, https:// doi.org/10.5194/acp-16-13561-2016.

Tsigaridis, K., and Coauthors, 2014: The AeroCom evaluation and intercomparison of organic aerosol in global models. Atmos. Chem. Phys., 14, 10845-10 895, https://doi.org/10.5194/acp-14-10845-2014.

U.S. EIA, 2011: Emissions of greenhouse gases in the United States 2009. Rep. DOI/EIA-0573(2009), U.S. Energy Information Administration, 77 pp., accessed 9 October 2017, www.eia.gov/environment /emissions/ghg_report/ghg_carbon.php.

U.S. EPA, 2016: Chemical Speciation Network (CSN). U.S. Environmental Protection Agency, accessed 5 June 2016, www3.epa.gov/ttnamti1/speciepg .html.

Wagner, N. L., and Coauthors, 2015: In situ vertical profiles of aerosol extinction, mass, and composition over the southeast United States during SENEX and SEAC4RS: Observations of a modest aerosol enhancement aloft. Atmos. Chem. Phys., 15, 7085-7102, https://doi.org/10.5194/acp-15-7085-2015.

Warneke, C., and Coauthors, 2012: Multiyear trends in volatile organic compounds in Los Angeles, California: Five decades of decreasing emissions. J. Geophys. Res., 117, D00V17, https://doi .org/10.1029/2012JD017899.

— surement strategy for the NOAA SENEX aircraft campaign as part of the Southeast Atmosphere Study 2013. Atmos. Meas. Tech., 9, 3063-3093, https://doi .org/10.5194/amt-9-3063-2016.

Washenfelder, R. A., and Coauthors, 2015: Biomass burning dominates brown carbon absorption in the rural southeastern United States. Geophys. Res. Lett., 42, 653-664, https://doi.org/10.1002/2014GL062444.

Weber, R. J., and Coauthors, 2007: A study of secondary organic aerosol formation in the anthropogenicinfluenced southeastern United States. J. Geophys. Res., 112, D13302, https://doi.org/10.1029/2007JD008408.

WHO, 2014: 7 million premature deaths annually linked to air pollution. World Health Organization, accessed 21 July 2016, www.who.int/mediacentre /news/releases/2014/air-pollution/en/.

Xie, Y., and Coauthors, 2013: Understanding the impact of recent advances in isoprene photooxidation on simulations of regional air quality. Atmos. Chem. Phys., 13, 8439-8455, https://doi.org/10.5194/acp -13-8439-2013.

Xiong, F., and Coauthors, 2015: Observation of isoprene hydroxynitrates in the southeastern United States and implications for the fate of $\mathrm{NO}_{\mathrm{x}}$. Atmos. Chem. Phys., 15, 11 257-11 272, https://doi.org/10.5194/acp $-15-11257-2015$.

$\mathrm{Xu}, \mathrm{L}$., and Coauthors, 2015a: Effects of anthropogenic emissions on aerosol formation from isoprene and monoterpenes in the southeastern United States. Proc. Natl. Acad. Sci. USA, 112, 37-42, https://doi .org/10.1073/pnas.1417609112.

— , S. Suresh, H. Guo, R. J. Weber, and N. L. Ng, 2015b: Aerosol characterization over the southeastern United States using high-resolution aerosol mass spectrometry: Spatial and seasonal variation of aerosol composition and sources with a focus on organic nitrates. Atmos. Chem. Phys., 15, 7307-7336, https:// doi.org/10.5194/acp-15-7307-2015.

Ye, C., and Coauthors, 2015: Comment on "Missing gas-phase source of HONO inferred from Zeppelin measurements in the troposphere." Science, 348, 1326-1326, https://doi.org/10.1126/science.aaa1992.

— , and Coauthors, 2016: Rapid cycling of reactive nitrogen in the marine boundary layer. Nature, 532, 489-491, https://doi.org/10.1038/nature17195.

You, Y., and Coauthors, 2014: Atmospheric amines and ammonia measured with a chemical ionization mass spectrometer (CIMS). Atmos. Chem. Phys., 14, 12181 12 194, https://doi.org/10.5194/acp-14-12181-2014.

Yu, S., and Coauthors, 2014: Attribution of the United States "warming hole": Aerosol indirect effect and precipitable water vapor. Sci. Rep., 4, 6929, https:// doi.org/10.1038/srep06929.

Yuan, B., and Coauthors, 2015: Airborne flux measurements of methane and volatile organic compounds over the Haynesville and Marcellus shale gas production regions. J. Geophys. Res. Atmos., 120, 6271-6289, https://doi.org/10.1002/2015JD023242.

Zhang, Q., and Coauthors, 2007: Ubiquity and dominance of oxygenated species in organic aerosols in anthropogenically-influenced Northern Hemisphere midlatitudes. Geophys. Res. Lett., 34, L13801, https:// doi.org/10.1029/2007GL029979. 


\section{EYEWITNESS \\ EVolution of the AtMospheric Sciences}

\section{by ROBERT G. FLEAGLE}

Eyewitness: Evolution of the Atmospheric Sciences describes how the atmospheric sciences were transformed in the span of the author's professional career from its origins in primitive weather forecasting to its current focus on

numerical modeling of environmental change. It describes

the author's observations of persons, events, and institutions beginning with graduate study during the Second World War and moving on to continuing expansion of the atmospheric sciences and technologies, through development of a major university department, development of new

scientific and professional institutions, and to the role that the science of the atmosphere now plays in climate change and other issues of social and political policy.

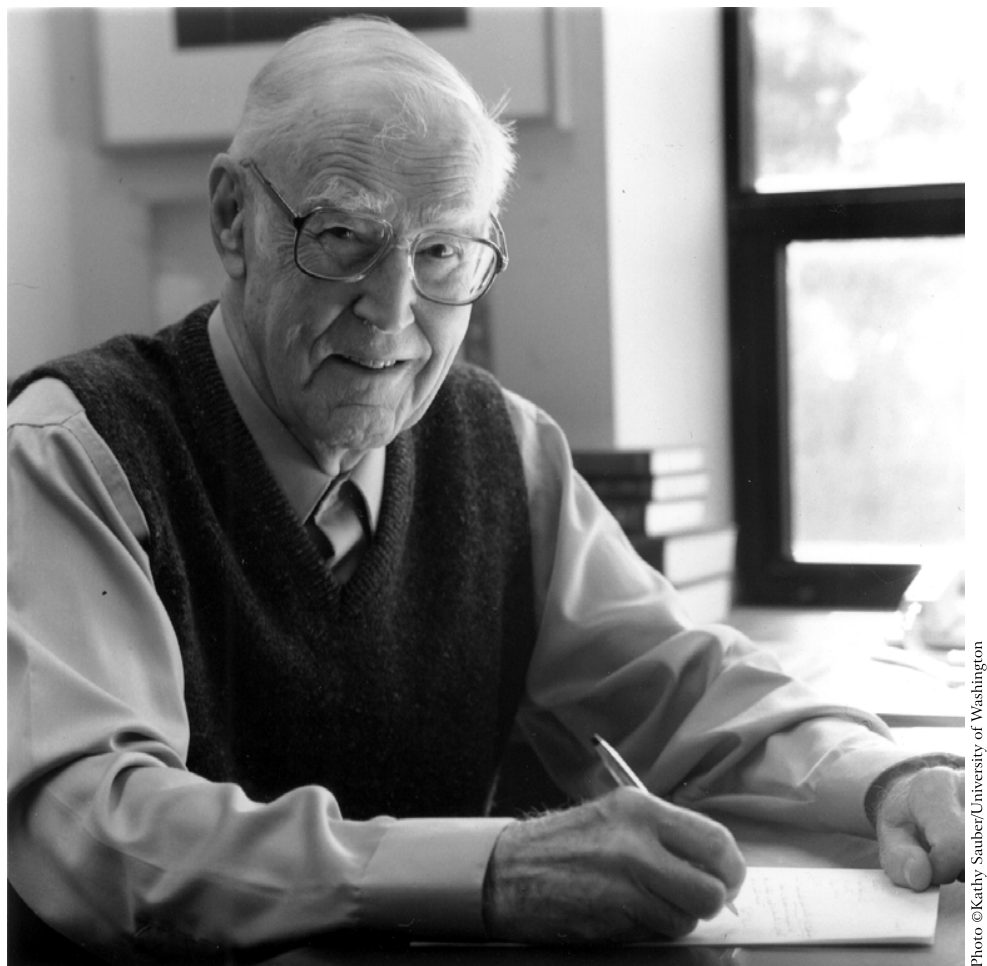

EYEWITNESS: EVOLUTION OF THE ATMOSPHERIC SCIENCES

ISBN 1-878220-39-X, 129 pp., hardbound, \$75 list/\$55 member.

Order online: www.ametsoc.org/amsbookstore

or see the order form at the back of this issue.

\section{ABOUT THE AUTHOR}

Robert G. Fleagle earned degrees in physics and meteorology at The Johns Hopkins University and New York University and began his professional career in 1948 at the University of Washington (UW). His research has focused on the structure of midlatitude cyclones, the physics and structure of the surface boundary layer, and processes of air-sea interaction. He is the author of about 100 papers published in scientific journals and of books on atmospheric physics and global environmental change. Applications of science to social and political policy have been important motivations for his career and have occupied his attention increasingly as the decades passed.

Fleagle participated at close range in the beginnings and growth of a major university department and of the University Corporation for Atmospheric Research (UCAR). In 1963 and 1964 he served as a staff specialist in the Office of Science and Technology, Executive Office of the President, and in 1977-78 he served as consultant to the National Oceanic and Atmospheric Administration. He has held many administrative posts including chairman of the UW Department of Atmospheric Sciences (1967-77), chairman of the National Academy of Sciences Committee on Atmospheric Sciences (1969-73), 